\title{
A current evaluation of the safety of angiotensin receptor blockers and direct renin inhibitors
}

\author{
This article was published in the following Dove Press journal: \\ Vascular Health and Risk Management \\ 17 May 20II \\ Number of times this article has been viewed
}

\author{
Helmy M Siragy \\ Professor of Medicine and \\ Endocrinology, Department of \\ Medicine, Director, Hypertension \\ Center, University of Virginia Health \\ System, Charlottesville, VA, USA
}

\begin{abstract}
The safety of angiotensin II receptor blockers (ARBs) for the treatment of hypertension and cardiovascular and renal diseases has been well documented in numerous randomized clinical trials involving thousands of patients. However, recent concerns have surfaced about possible links between ARBs and increased risks of myocardial infarction and cancer. Less is known about the safety of the direct renin inhibitor aliskiren, which was approved as an antihypertensive in 2007. This article provides a detailed review of the safety of ARBs and aliskiren, with an emphasis on the risks of cancer and myocardial infarction associated with ARBs. Safety data were identified by searching PubMed and Food and Drug Administration (FDA) Web sites through April 2011. ARBs are generally well tolerated, with no known class-specific adverse events. The possibility of an increased risk of myocardial infarction associated with ARBs was suggested predominantly because the Valsartan Antihypertensive Long-Term Use Evaluation (VALUE) trial reported a statistically significant increase in the incidence of myocardial infarction with valsartan compared with amlodipine. However, no large-scale, randomized clinical trials published after the VALUE study have shown a statistically significant increase in the incidence of myocardial infarction associated with ARBs compared with placebo or non-ARBs. Meta-analyses examining the risk of cancer associated with ARBs have produced conflicting results, most likely due to the inherent limitations of analyzing heterogeneous data and a lack of published cancer data. An ongoing safety investigation by the FDA has not concluded that ARBs increase the risk of cancer. Pooled safety results from clinical trials indicate that aliskiren is well tolerated, with a safety profile similar to that of placebo. ARBs and aliskiren are well tolerated in patients with hypertension and certain cardiovascular and renal conditions; their benefits outweigh possible safety concerns.
\end{abstract}

Keywords: angiotensin II receptor blocker, renin-angiotensin system, aliskiren, safety, myocardial infarction, cancer

\section{Introduction}

The renin-angiotensin system (RAS) consists of a group of hormones, which regulates blood pressure (BP), fluid and electrolyte balance, tissue perfusion, and vascular growth. ${ }^{1,2}$ The RAS plays an important role in the pathophysiology of cardiovascular and renal disease, ${ }^{3}$ and antihypertensive therapies that target the RAS are used in the management of hypertension, congestive heart failure, myocardial infarction, stroke, high cardiovascular risk, diabetes, and renal failure. ${ }^{2,3}$ In addition, antihypertensive drugs that block the RAS may provide organ protection by acting on local RAS functions in tissues, such as the kidneys, heart, eyes, and brain., ${ }^{2,3}$

Angiotensin-converting enzyme (ACE) inhibitors (eg, ramipril, captopril, enalapril, fosinopril) were the first class of RAS-blocking agents to become available, and ACE
Correspondence: Helmy M Siragy University of Virginia, Box 801409, Charlottesville, VA, 22908, USA

Tel + I-4349245629

$\mathrm{Fax}+\mathrm{I} 4349823626$

Email hms7a@virginia.edu 
inhibitors have been a cornerstone of antihypertensive therapy for many years. ${ }^{4}$ Numerous clinical trials have shown that the BP-lowering effects of ACE inhibitors provide cardiovascular protection; ${ }^{5}$ however, ACE inhibitors are associated with treatment-related adverse events (AEs) including persistent dry cough ${ }^{6,7}$ and angioedema. ${ }^{8}$ Both of these AEs are more common among black and Asian patients compared with white patients, ${ }^{5,8}$ and cough is also more common among women and nonsmokers. ${ }^{7}$ Cough is typically managed by discontinuing ACE inhibitor therapy or by decreasing the dose. Antitussives and antihistamines are usually ineffective for managing cough; however, in some cases cough may disappear spontaneously. ${ }^{6}$ Strategies for managing angioedema include discontinuation of ACE inhibitor therapy and/or treatment with antihistamines or epinephrine. ${ }^{8}$ Further, although several case reports have suggested a relationship between the use of ACE inhibitors and development of cancer, casecontrol and longitudinal studies have shown no relationship and, in some cases, a protective effect from treatment.9,10

Over the last two decades, several angiotensin II receptor blockers (ARBs; eg, losartan, valsartan, telmisartan, olmesartan) have been approved as antihypertensive therapies. ${ }^{11}$ ARBs provide clinically meaningful benefits for patients with cardiovascular and/or renal disease, ${ }^{11}$ and ARBs generally have better tolerability profiles than ACE inhibitors. ${ }^{12}$ Cough is not an AE associated with ARB therapy; however, when ARBs are used in combination with ACE inhibitors, there is an increased risk of renal dysfunction and hyperkalemia. ${ }^{4}$ Over the past several years, concerns have surfaced about possible links between ARBs and increased risks of cancer ${ }^{13}$ and myocardial infarction. ${ }^{14}$

Direct renin inhibitors (DRIs) are a new class of antihypertensive agents that target the initial rate-limiting step of the RAS. ${ }^{15}$ Several DRIs have been developed as antihypertensive therapies; however, early DRIs, including enalakiren, remikiren, and zankiren, had poor bioavailability, weak antihypertensive effects, and short durations of action. ${ }^{4,15}$ Aliskiren is the only DRI that is approved by the United States Food and Drug Administration (FDA) for the treatment of hypertension, ${ }^{16}$ but several other DRIs are in the early stages of clinical development. ${ }^{17,18}$ In clinical studies, the AE profile of aliskiren was similar to that of placebo, with a lower incidence of cough than ACE inhibitors. ${ }^{15,16}$

The main purpose of this article is to review the safety of ARBs and the DRI aliskiren, including a detailed examination of the risks of cancer and myocardial infarction associated with ARBs. A brief overview of the RAS and efficacy of ARBs and aliskiren is also provided.

\section{Overview of the RAS}

Key steps in the RAS are shown in Figure $1 .{ }^{3}$ Following conversion from its precursor prorenin, the aspartate protease renin is secreted by granular cells of the juxtaglomerular apparatus in the kidney. ${ }^{3,19}$ The biosynthesis and release of renin are key elements in determining the capacity of the RAS to regulate BP and respond to fluid changes. ${ }^{3}$ Renin catalyzes the conversion of angiotensinogen to angiotensin I, which is the rate-limiting step in the RAS. ${ }^{15}$ DRIs block this step and reduce plasma renin activity. ${ }^{15}$ ACE catalyzes the conversion of angiotensin I to angiotensin II, and ACE inhibitors block this step in the RAS. ${ }^{15}$ Angiotensin II binds to angiotensin II type-1 ( $\mathrm{AT}_{1}$ ) receptors, which regulates BP via several mechanisms and provides feedback inhibition of further release of renin by the kidneys. ${ }^{15} \mathrm{ARBs}$ block the $\mathrm{AT}_{1}$ receptor, reducing the effects of angiotensin II. ${ }^{4}$

ARBs and ACE inhibitors may not provide comprehensive suppression of the RAS because they disrupt the negative feedback effect of angiotensin II on renin release, resulting in an increase in plasma renin concentration and plasma renin activity. ${ }^{2,4} \mathrm{ACE}$ inhibitors also increase angiotensin I concentrations, and although ACE inhibitors prevent the conversion of angiotensin I to angiotensin II, angiotensin II production can still occur through non-ACE-dependent pathways involving enzymes such as chymase and chymotrypsin-like angiotensin-generating enzyme. ${ }^{1,15}$ In addition, ACE inhibitors block the degradation of bradykinin, and the resulting increase in bradykinin concentration may be a factor in the development of cough and angioedema associated with these agents. ${ }^{15}$ DRIs may provide more optimal suppression of the RAS by interrupting the system at its first regulated step, resulting in decreased plasma renin activity. ${ }^{1,2,15}$

\section{Efficacy of ARBs and the DRI aliskiren}

In 1995, losartan was the first ARB to receive FDA approval as an antihypertensive. Since then, six other ARBs and the DRI aliskiren have also been approved for the treatment of hypertension; several of these agents also have other cardiovascular indications. ${ }^{20}$ Approved indications, dosing information, and dates of FDA approval for the ARBs and aliskiren are shown in Table 1.

\section{ARBs}

Data from numerous randomized clinical trials indicate that ARB therapy is effective in reducing complications related to hypertension ${ }^{5}$ and in slowing or blocking the progression of cardiovascular disease. ${ }^{11}$ As a class of drugs, ARBs have 


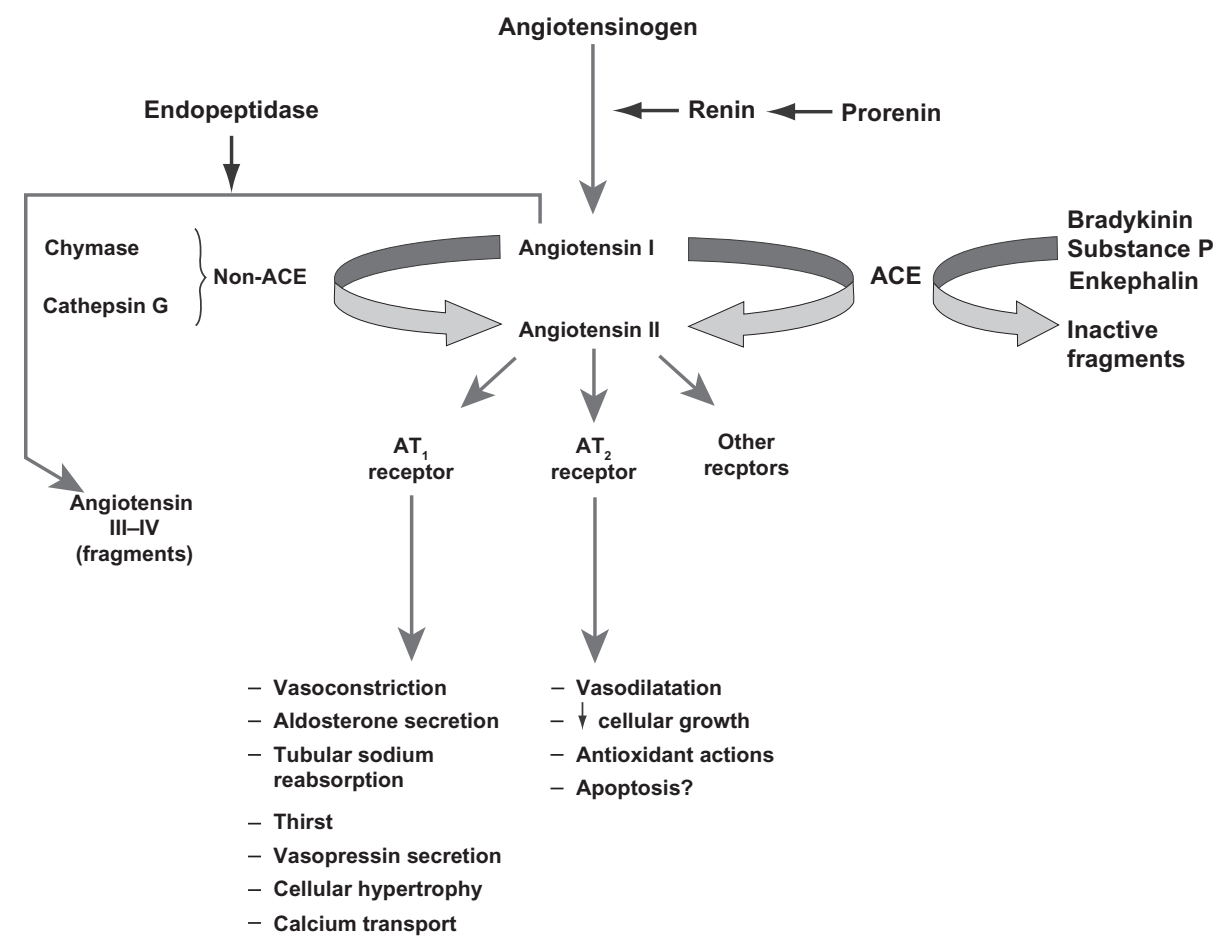

Figure I Overview of the renin-angiotensin system.

Reproduced with permission of the American Society of Nephrology, from 'The renin-angiotensin system as a risk factor and therapeutic target for cardiovascular and renal disease', Volpe et al, volume 13, supplement 3, 2002; permission conveyed through Copyright Clearance Center, Inc. ${ }^{3}$

Abbreviations: ACE, angiotensin-converting enzyme; $\mathrm{AT}_{1} / \mathrm{AT}_{2}$, angiotensin type $\mathrm{I} / 2$.

shown clinical benefits for patients with heart failure, diabetes, and chronic kidney disease. ${ }^{5}$ Pharmacologic and dosing differences exist among the seven ARBs approved as antihypertensive agents; ${ }^{11,20}$ therefore, efficacy and safety results for one ARB cannot be extrapolated to other ARBs. ${ }^{20}$ In general, newer ARBs are more effective than losartan in lowering BP in patients with hypertension based on the results of head-tohead comparative studies. ${ }^{11}$ Recent reviews ${ }^{11,20}$ have compared the efficacy of ARBs vs non-ARBs in different clinical settings. These results are summarized in Table 2.

\section{The DRI aliskiren}

The effects of aliskiren on cardiovascular and renal morbidity and mortality are currently unknown. However, several outcomes studies are underway as part of the ASPIRE HIGHER clinical trials program, which will help to better define the role of direct renin inhibition in clinical practice. ${ }^{1}$

When administered alone or in combination with other agents, including thiazide diuretics, calcium-channel blockers, or RAS-blocking drugs (ie, ACE inhibitors or ARBs), treatment with aliskiren effectively lowers BP in a variety of hypertensive populations (eg, diabetic, obese, elderly)., ${ }^{1,21}$ In several randomized, double-blind clinical trials, treatment with aliskiren has been associated with positive effects on surrogate markers of cardiovascular and renal disease, including urinary albumin, N-terminal pro-brain natriuretic peptide (NT-proBNP), and left ventricular mass index. ${ }^{22-24}$ For example, in the Aliskiren in the Evaluation of Proteinuria in Diabetes (AVOID) trial in patients with hypertension and type 2 diabetes with nephropathy, ${ }^{22}$ aliskiren $300 \mathrm{mg}$ /day combined with losartan $100 \mathrm{mg} /$ day reduced the mean urinary albuminto-creatinine ratio by $20 \%$ (95\% confidence interval [CI]: $9 \%$ to $30 \% ; P<0.001)$ compared with losartan $100 \mathrm{mg} /$ day plus placebo. In the Aliskiren Observation of Heart Failure Treatment (ALOFT) trial ${ }^{23}$ involving patients with New York Heart Association (NYHA) class II to IV heart failure and a history of hypertension, addition of aliskiren to an ACE inhibitor (or $\mathrm{ARB}$ ) and $\beta$-blocker significantly reduced NT-proBNP concentrations compared with placebo. In the Aliskiren in Left Ventricular Hypertrophy (ALLAY) trial, ${ }^{24}$ which included overweight patients with hypertension and increased ventricular wall thickness, treatment with aliskiren or losartan resulted in similar reductions in left ventricular mass index.

In a recent study (Aliskiren Study in Post-MI Patients to Reduce Remodeling [ASPIRE]), adding aliskiren to standard therapy (ie, statins, beta-blockers, antiplatelets, and either ACE inhibitors [given to $90 \%$ of the patients] or ARBs [ $10 \%$ of the patients]) in the weeks following an acute 


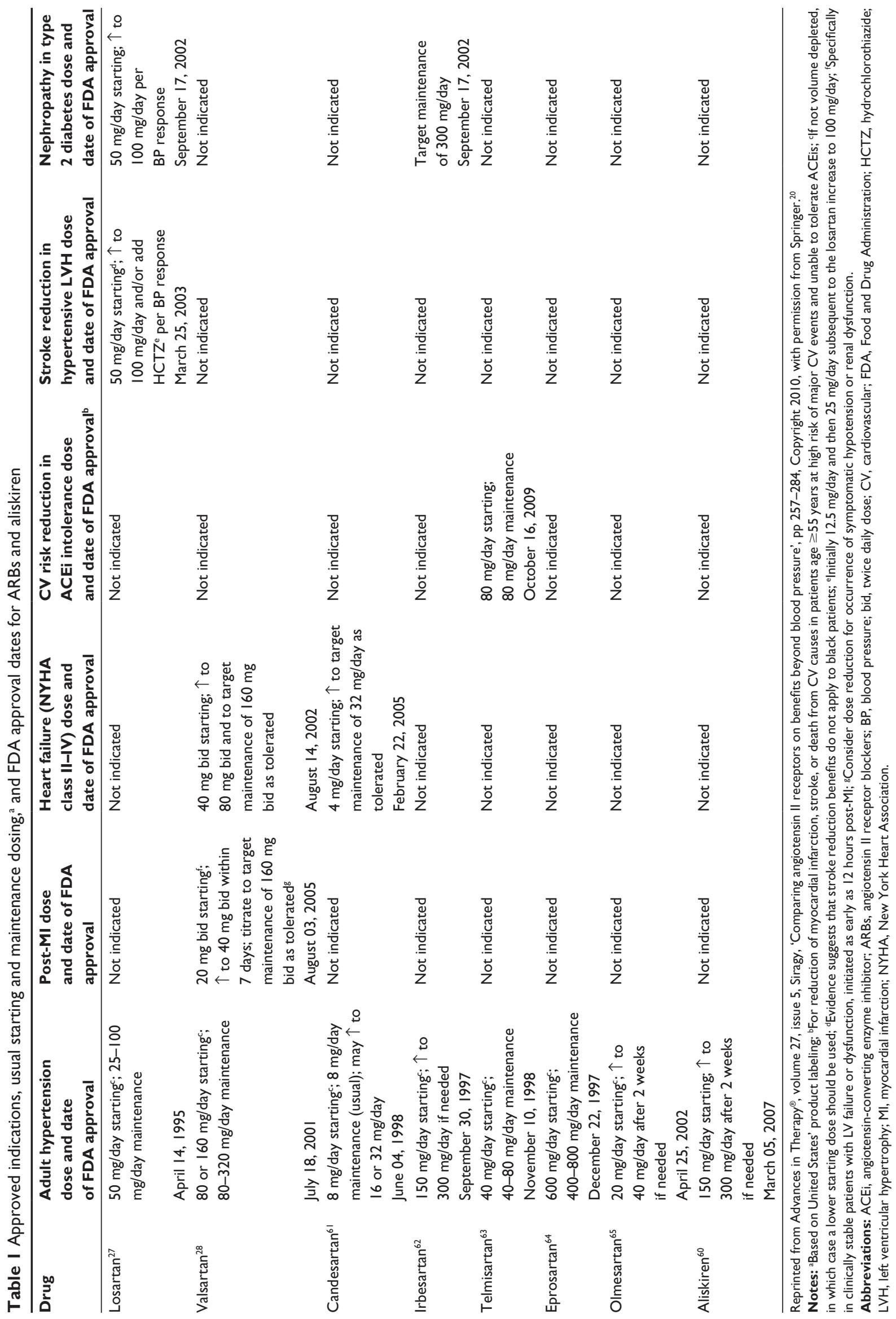


Table 2 Selected outcomes from randomized clinical trials of ARBs

\begin{tabular}{|c|c|c|c|c|c|c|c|}
\hline Drug & Atherosclerosis & $\begin{array}{l}\text { Hypertensive } \\
\text { LVH }\end{array}$ & $\begin{array}{l}2^{\circ} \text { prevention } \\
\text { post-MI }\end{array}$ & Stroke & $\begin{array}{l}\text { Heart } \\
\text { failure }\end{array}$ & $\begin{array}{l}\text { Atrial } \\
\text { fibrillation }\end{array}$ & Renoprotection \\
\hline Losartan & $+1-$ & $\begin{array}{l}+ \\
\text { (LIFE) }\end{array}$ & $\begin{array}{l}- \\
\text { (OPTIMAL) }\end{array}$ & $\begin{array}{l}+ \\
\left(\text { LIFE*) }^{*}\right. \\
2^{\circ} \text { prevent: }+ \\
\text { (LIFE) }\end{array}$ & $\begin{array}{l}+/- \\
\text { (ELITE/ } \\
\text { ELITE II) }\end{array}$ & $\begin{array}{l}\mathrm{I}^{\circ} \text { prevent: + } \\
\text { (LIFE) }\end{array}$ & $\begin{array}{l}+ \\
\text { (RENAAL, JLIGHT, } \\
\text { ROAD) }\end{array}$ \\
\hline Valsartan & $\begin{array}{l}+ \\
(\text { MARVAL-2, } \\
\text { VIP) }\end{array}$ & + & $\begin{array}{l}+ \\
(T-V E N T U R E, \\
\text { VALIANT) }\end{array}$ & $\begin{array}{l}+ \\
\text { (jikei Heart*, } \\
\text { Kyoto HEART*) }\end{array}$ & $\begin{array}{l}+ \\
(\mathrm{Val}-\mathrm{HeFT})\end{array}$ & $\begin{array}{l}I^{\circ} \text { prevent: }+ \\
(\text { Val-HeFT) } \\
2^{\circ} \text { prevent: }- \\
\text { GISSI-AF) }\end{array}$ & $\begin{array}{l}+ \\
\text { (VALERIA, SMART, } \\
\text { HKVIN, MARVAL, } \\
\text { MARVAL-2) }\end{array}$ \\
\hline Candesartan & $\begin{array}{l}+ \\
(\text { CENTRO, } \\
\text { MIT EC) }\end{array}$ & $\begin{array}{l}+ \\
(\mathrm{CATCH}, \\
\text { CASE-J) }\end{array}$ & $\begin{array}{l}- \\
(\mathrm{E}-\mathrm{COST})\end{array}$ & $\begin{array}{l}+ \\
\left(S C O P{ }^{*}\right) \\
1^{\circ} \text { prevent: - } \\
(\text { E-COST) } \\
2^{\circ} \text { prevent: + } \\
(\text { E-COST) }\end{array}$ & $\begin{array}{l}+ \\
\text { (RESOLVD, } \\
\text { CHARM) }\end{array}$ & $\begin{array}{l}2^{\circ} \text { prevent: - } \\
\text { (CAPRAF) }\end{array}$ & $\begin{array}{l}+l- \\
(\text { DIRECT, } \\
\text { CENTRO) }\end{array}$ \\
\hline Irbesartan & $\begin{array}{l}+ \\
(\text { EPAS, ISLAND, } \\
\text { SILVHIA) }\end{array}$ & $\begin{array}{l}+ \\
(\text { SILVHIA, } \\
\text { CVIP) }\end{array}$ & & & $\begin{array}{l}+ \\
\text { (I-PRESERVE) }\end{array}$ & $2^{\circ}$ prevent: + & $\begin{array}{l}+/- \\
\text { (IRMA-2, IDNT, } \\
\text { IMPROVE) }\end{array}$ \\
\hline Telmisartan & + & $\begin{array}{l}+ \\
\text { (ONTARGET/ } \\
\text { TRANSCEND) }\end{array}$ & & $\begin{array}{l}- \\
\text { (TRANSCEND*,i) } \\
2^{\circ} \text { prevent: }- \\
\text { (PROFESS) }\end{array}$ & $\begin{array}{l}+ \\
\text { (REPLACE) }\end{array}$ & $1^{\circ}$ prevent: + & $\begin{array}{l}+/- \\
\text { (INNOVATION, } \\
\text { TRANSCEND, } \\
\text { ONTARGET, } \\
\text { DETAIL) }\end{array}$ \\
\hline Eprosartan & + & + & & $\begin{array}{l}2^{\circ} \text { prevent: + } \\
\text { (MOSES) }\end{array}$ & $\begin{array}{l}+ \\
\text { (ADEPT) }\end{array}$ & & \\
\hline Olmesartan & $\begin{array}{l}+ \\
\text { (EUTOPIA) }\end{array}$ & - & & & & & \\
\hline
\end{tabular}

Reprinted from Advances in Therapy ${ }^{\circledR}$, volume 27, issue 5, Siragy, 'Comparing angiotensin II receptors on benefits beyond blood pressure', pP 257-284, Copyright 2010, with permission from Springer. ${ }^{20}$

Notes: + designates that the study achieved its primary or secondary endpoint(s); - designates that study did not meet its primary or secondary endpoint(s); This table is a summary of fully published randomized controlled trial data (ie, no data from single-arm noncomparative trials were considered), with an emphasis on large-scale trials (when available). Additional smaller studies were considered in the absence of data from large-scale clinical trials; *Stroke data were not specific to primary or secondary prevention in the main analysis; 'Stroke was evaluated in a post-hoc analysis, not as a prespecified endpoint.

Abbreviations: ADEPT, Addition of the ATI Receptor Antagonist Eprosartan to ACE Inhibitor Therapy in Chronic Heart Failure trial; ARBs, angiotensin receptor blockers; CAPRAF, Candesartan in the Prevention of Relapsing Atrial Fibrillation; CASE-J, Candesartan Antihypertensive Survival Evaluation in Japan; CATCH, Candesartan Assessment in the Treatment of Cardiac Hypertrophy; CENTRO, Candesartan on Atherosclerotic Risk Factors; CHARM, Candesartan in Heart Failure Assessment in Reduction of Mortality; CVIP, Cardiovascular Irbesartan Project; DETAIL, Diabetics Exposed to Telmisartan and Enalapril; DIRECT, Diabetic Retinopathy Candesartan Trials; E-COST, Efficacy of Candesartan on Outcome in Saitama Trial; ELITE, Evaluation of Losartan in the Elderly; EPAS, Endothelial Protection, ATI Blockade and CholesterolDependent Oxidative Stress; EUTOPIA, European Trial on Olmesartan and Pravastatin in Inflammation and Atherosclerosis; GISSI-AF, Gruppo Italiano per lo Studio della Sopravvivenza nell'Infarto Miocardico-Atrial Fibrillation; HKVIN, Hong Kong Study Using Valsartan in IgA Nephropathy; IDNT, Irbesartan in Diabetic Nephropathy Trial; IMPROVE, Irbesartan in the Management of Proteinuric Patients at High Risk of Vascular Events; INNOVATION, Incipient to Overt: Angiotensin II Blocker, Telmisartan, Investigation on Type 2 Diabetic Nephropathy; I-PRESERVE, Irbesartan in Heart Failure with Preserved Systolic Function; IRMA-2, Irbesartan in Microalbuminuria, Type 2 Diabetic Nephropathy Trial; ISLAND, Irbesartan and Lipoic Acid in Endothelial Dysfunction; JLIGHT, Japanese Losartan Therapy Intended for the Global Renal Protection in Hypertensive Patients; LIFE, Losartan Intervention For Endpoint Reduction in Hypertension; LVH, left ventricular hypertrophy; MARVEL/MARVEL-2, Microalbuminuria Reduction with Valsartan; MI, myocardial infarction; MIT-EC, Media Intima Thickness Evaluation with Candesartan Cilexetil; MOSES, Morbidity and Mortality after Stroke, Eprosartan Compared with Nitrendipine for Secondary Prevention; OPTIMAL, Optimal Trial In Myocardial Infarction with the Angiotensin Receptor Blocker Losartan; ONTARGET, Ongoing Telmisartan Alone and in Combination with Ramipril Global Endpoint Trial; PROFESS, The Prevention Regimen for Effectively Avoiding Second Strokes Trial; RENAAL, Reduction of Endpoints in Non-insulin-dependent Diabetes Mellitus with Angiotensin II Antagonist Losartan; REPLACE, Replacement of AngiotensinConverting Enzyme Inhibition; RESOLVD, Randomized Evaluation of Strategies for Left Ventricular Dysfunction; ROAD, Renoprotection of Optimal Antiproteinuric Doses; SCOPE, Study on Cognition and Prognosis in the Elderly; SILVHIA, Swedish Irbesartan Left Ventricular Hypertrophy Versus Atenolol; SMART, Shiga Microalbuminuria Reduction Trial; TRANSCEND, Telmisartan Randomized Assessment Study in ACE Intolerant Subjects with Cardiovascular Disease; T-VENTURE, Inhibitory Effect of Valsartan against Progression of Left Ventricular Dysfunction after Myocardial Infarction; VALERIA, Valsartan in Combination with Lisinopril in Hypertensive Patients with Microalbuminuria; VALIANT, Valsartan in Acute Myocardial Infarction; Val-HeFT, Valsartan Heart Failure Trial; VIP, Valsartan Inhibits Platelets.

myocardial infarction gave no further protection against ventricular remodeling. ${ }^{25}$ However, the researchers conducted a post-hoc subgroup analysis and found that patients with diabetes $(n=148)$ were the only subgroup that had a borderline interaction in treatment effect. There were more AEs in patients assigned to aliskiren, but the total number of serious AEs was similar in the two arms. Specifically, AEs that occurred at a higher incidence in aliskiren recipients compared with placebo recipients included hyperkalemia (5.2\% vs $1.3 \%)$, hypotension ( $8.8 \%$ vs $4.5 \%)$, and renal dysfunction (2.4\% vs $0.8 \%$ ). Elevations in blood urea nitrogen and creatinine were more likely in the aliskiren group, 
and patients assigned to aliskiren were more likely to have a potassium value measured at $>5.5 \mathrm{mmol} / \mathrm{L}$ or at $\geq 6 \mathrm{mmol} / \mathrm{L}$. Although these results do not provide support for testing the use of aliskiren in a morbidity and mortality trial in this population of high-risk postmyocardial infarction patients, ASPIRE used a surrogate endpoint and was not powered to assess hard clinical outcomes. Aliskiren is currently being studied in ongoing outcomes trials of patients with chronic heart failure and diabetic nephropathy to assess the role of direct renin inhibition in these populations.

\section{Safety of ARBs and the DRI aliskiren Safety of ARBs}

As a class of agents, ARBs are well tolerated, with safety profiles similar to that of placebo. No class-specific AEs have been associated with ARBs. ${ }^{26}$ ARBs are contraindicated for women who are pregnant or may become pregnant because of the risk of fetal developmental abnormalities, and ARBs are not recommended for women who are breastfeeding. ${ }^{5}$ Several antihypertensive drugs have been associated with an increased risk of erectile dysfunction (ED); however, ARBs have not been observed to increase the risk of ED. ${ }^{5}$ In patients whose renal function may depend on the activity of the RAS (eg, patients with severe congestive heart failure), treatment with ARBs may be associated with oliguria and/or progressive azotemia; rarely, acute renal failure and/or death have been reported in these patients. ARBs may also increase serum creatinine and/or blood urea nitrogen levels in patients with unilateral or bilateral renal-artery stenosis..$^{27,28}$

\section{ARBs and myocardial infarction}

In 2004, an editorial by Verma and Strauss ${ }^{14}$ raised concerns that ARBs may increase the risk of myocardial infarction based on results of the Valsartan Antihypertensive LongTerm Use Evaluation (VALUE) trial, ${ }^{29}$ which reported a statistically significant $19 \%$ relative increase in myocardial infarction with valsartan compared with the calcium-channel blocker amlodipine. Responses to this article from the medical community were mixed. Several follow-up editorials and analyse ${ }^{30-33}$ cited the need to evaluate the risk of myocardial infarction associated with ARBs more systematically and in a broader clinical context. However, other publications noted that there are possible mechanisms by which ARBs could predispose patients to myocardial infarction. ${ }^{12,34}$

In 2006, Strauss and Hall'12 used the term "ARB-MI Paradox" to describe the unexpected observation that in some clinical trials involving patients at high cardiovascular risk, the BP-lowering effects of ARBs did not reduce the risk of myocardial infarction compared with placebo, and in some cases treatment with ARBs may have increased the risk of myocardial infarction. The authors went on to provide a plausible biological mechanism by which ARBs could increase the incidence of myocardial infarction by increasing circulating levels of angiotensin II. Increased angiotensin II levels cause up-regulation of angiotensin type-2 $\left(\mathrm{AT}_{2}\right)$ receptors. While $\mathrm{AT}_{2}$-receptor stimulation may provide beneficial effects by mediating vasodilation and nitric oxide release, $\mathrm{AT}_{2}$-receptor stimulation may also mediate growth promotion, fibrosis, and hypertrophy, and may have pro-atherogenic and pro-inflammatory effects. The authors concluded that results from meta-analyses ${ }^{35-38}$ support the "ARB-MI Paradox" because they show that ARBs are associated with an increased risk of coronary heart disease events and/or a lack of BP-related vascular benefits.

Following the publication of the editorial by Verma and Strauss, ${ }^{14}$ several meta-analyses were performed analyzing cardiovascular event outcomes across multiple clinical trials involving ARBs. Results of these analyses were mixed, with some studies reporting no increased risk of myocardial infarction associated with ARBs, ${ }^{33,35,36}$ while other studies ${ }^{12,39}$ report a trend toward increased risk of myocardial infarction with ARBs. While meta-analyses can be powerful tools to summarize data across multiple studies, they also have significant limitations. ${ }^{40}$ Identification and selection of studies can be biased and availability of results may limit the analyses that can be performed. The choice of statistical analysis methods (ie, fixed-effects vs random-effects models) can also affect the outcome of the meta-analysis. In addition, heterogeneity of data between different studies (eg, disease states, follow-up time, treatment regimens) may make it difficult to create a meaningful integration of results. ${ }^{40}$ Limitations specifically acknowledged in the meta-analyses that evaluated the risk of myocardial infarction associated with ARBs included heterogeneity of data across studies, limited availability of data on the incidence of myocardial infarction, varying definitions of myocardial infarction between studies, and the potential for confounding effects of different treatments on the incidence of myocardial infarction. ${ }^{35,36}$

Table 3 shows the incidence of myocardial infarction reported in randomized clinical trials of ARBs that had a mean or median follow-up time of at least 1 year and enrolled at least 1000 patients with a range of cardiovascular and renal conditions. Since the publication of the Verma and Strauss editorial, ${ }^{14}$ considerably more data have become available on the incidence of myocardial infarction 
Table 3 Fatal and nonfatal myocardial infarction in clinical trials of ARBs

\begin{tabular}{|c|c|c|c|c|c|c|}
\hline Trial & Year & Condition & Treatment arms & $\begin{array}{l}\text { Total patients } \\
\text { (N) }\end{array}$ & $\begin{array}{l}\text { Follow-up } \\
\text { (years) }\end{array}$ & $\begin{array}{l}\text { Patients with MI } \\
\text { n (\%) }\end{array}$ \\
\hline \multirow[t]{3}{*}{ NAVIGATOR ${ }^{44}$} & 2010 & Impaired glucose & Placebo & 4675 & 5.0 & $140(3.0)$ \\
\hline & & tolerance $+\mathrm{CV}$ disease & Valsartan & 4631 & & $138(3.0)$ \\
\hline & & or $\mathrm{CV}$ risk factors & & & & \\
\hline \multirow[t]{2}{*}{ KYOTO HEART ${ }^{45}$} & 2009 & Uncontrolled hypertension & Non-ARB therapy & 1514 & 3.3 & II (0.7) \\
\hline & & & Valsartan & 1517 & & $7(0.5)$ \\
\hline \multirow[t]{3}{*}{ ONTARGET ${ }^{42}$} & 2008 & Vascular disease or & Ramipril & 8576 & 4.7 & $413(4.8)$ \\
\hline & & high-risk diabetes & Telmisartan & 8542 & & $440(5.2)$ \\
\hline & & & Ramipril + telmisartan & 8502 & & $438(5.2)$ \\
\hline \multirow[t]{2}{*}{ TRANSCEND ${ }^{43}$} & 2008 & ACEi intolerant $+\mathrm{CV}$ disease or & Placebo & 2972 & 4.7 & $147(5.0)$ \\
\hline & & diabetes with end-organ damage & Telmisartan & 2954 & & $116(3.9)$ \\
\hline \multirow[t]{2}{*}{ I-PRESERVE ${ }^{47}$} & 2008 & Heart failure + LV ejection & Placebo & 2061 & 4.1 & $54(2.6)$ \\
\hline & & fraction $\geq 45 \%$ & Irbesartan & 2067 & & $60(2.9)$ \\
\hline \multirow[t]{2}{*}{ PROFESS ${ }^{48}$} & 2008 & Ischemic stroke & Placebo & 10,186 & 2.5 & $169(1.7)$ \\
\hline & & & Telmisartan & 10,146 & & $168(1.7)$ \\
\hline \multirow[t]{3}{*}{ JIKEI } & 2007 & Hypertension, coronary & Non-ARB therapy & 1540 & 3.1 & $19(1.2)$ \\
\hline & & artery disease and/or & Valsartan & $154 \mid$ & & $17(1.1)$ \\
\hline & & heart failure & & & & \\
\hline \multirow[t]{2}{*}{$\mathrm{E}-\operatorname{COST}^{41}$} & 2005 & Essential hypertension & Conventional therapy & 995 & 3.1 & $23(2.8)^{\mathrm{a}}$ \\
\hline & & & Candesartan & 1053 & & $10(1.2)^{\mathrm{a}}$ \\
\hline \multirow[t]{2}{*}{ VALUE $^{29}$} & 2004 & Hypertension risk factors & Amlodipine & 7596 & 4.2 & $313(4.1)$ \\
\hline & & & Valsartan & 7649 & & $369(4.8)$ \\
\hline \multirow[t]{2}{*}{$\mathrm{SCOPE}^{55}$} & 2003 & Elderly hypertension & Placebo & 2460 & 3.7 & $63(2.6)$ \\
\hline & & & Candesartan & 2477 & & $70(2.8)$ \\
\hline \multirow[t]{2}{*}{ CHARM $^{66,67}$} & 2003 & Heart failure & Placebo & 3796 & 3.1 & $190(5.0)$ \\
\hline & & & Candesartan & 3803 & & $176(4.6)$ \\
\hline \multirow[t]{3}{*}{ CHARM-Added ${ }^{68}$} & 2003 & CHF + LV ejection & Placebo & 1272 & 3.4 & $69(5.4)$ \\
\hline & & fraction $\leq 40 \%$, being & Candesartan & 1276 & & $44(3.4)$ \\
\hline & & treated with ACEis & & & & \\
\hline \multirow[t]{3}{*}{ CHARM Alternative $^{69}$} & 2003 & ACEi intolerant, symptomatic & Placebo & 1015 & 2.8 & $48(4.7)$ \\
\hline & & heart failure, + LV ejection & Candesartan & 1013 & & $75(7.4)$ \\
\hline & & fraction $\leq 40 \%$ & & & & \\
\hline \multirow[t]{2}{*}{ CHARM Preserved ${ }^{70}$} & 2003 & $\mathrm{CHF}+\mathrm{LV}$ ejection & Placebo & 1509 & 3.0 & $73(4.8)$ \\
\hline & & fraction $>40 \%$ & Candesartan & 1514 & & $57(3.8)$ \\
\hline \multirow[t]{3}{*}{ VALIANT T1,72 } & 2003 & $\mathrm{MI}+$ heart failure and/or & Captopril & 4909 & 2.1 & $559(11.4)^{b}$ \\
\hline & & LV dysfunction & Valsartan & 4909 & & $587(12.0)^{\mathrm{b}}$ \\
\hline & & & Captopril + valsartan & 4885 & & $554(11.3)^{b}$ \\
\hline \multirow[t]{2}{*}{ LIFE $^{73}$} & 2002 & Hypertension + LV & Atenolol & 4588 & 4.8 & $188(4.1)$ \\
\hline & & hypertrophy & Losartan & 4605 & & $198(4.3)$ \\
\hline \multirow[t]{2}{*}{ OPTIMAAL ${ }^{74}$} & 2002 & $\mathrm{MI}$ & Captopril & 2733 & 2.7 & $379(13.9)$ \\
\hline & & & Losartan & 2744 & & $384(14.0)$ \\
\hline \multirow[t]{3}{*}{ IDNT $^{75}$} & 2001 & Diabetic nephropathy & Placebo & 569 & 2.6 & $51(9.0)$ \\
\hline & & & Irbesartan & 579 & & $48(8.3)$ \\
\hline & & & Amlodipine & 567 & & $29(5.1)$ \\
\hline \multirow[t]{2}{*}{ RENAAL $^{76}$} & 2001 & Diabetic nephropathy & Placebo & 762 & 3.4 & $68(8.9)$ \\
\hline & & & Losartan & 751 & & $50(6.7)$ \\
\hline \multirow[t]{2}{*}{ ELITE $\|^{77}$} & 2000 & Heart failure + ejection & Captopril & 1574 & 1.5 & $28(1.8)$ \\
\hline & & fraction $\leq 40 \%$ & Losartan & 1578 & & $31(2.0)$ \\
\hline
\end{tabular}

Notes: aPercentages reported in the E-COST study are based on the intent-to-treat population ( $\mathrm{n}=8 \mathrm{I} 5$ for both treatment groups); ${ }^{\text {b }} \mathrm{Number}$ (\%) of patients who had $\geq$ I MI; Because patients could have more than I MI, the number of investigator-reported Mls was 798 in the captopril group, 796 in the valsartan group, and 756 in the captopril + valsartan group.

Abbreviations: ACEi, angiotensin-converting enzyme inhibitor; ARB, angiotensin II receptor blocker; CHARM, Candesartan in Heart Failure Assessment in Reduction of Mortality; CHF, congestive heart failure; CV, cardiovascular; E-COST, Efficacy of Candesartan on Outcome in Saitama Trial; ELITE, Evaluation of Losartan in the Elderly; IDNT, Irbesartan Diabetic Nephropathy Trial; I-PRESERVE, Irbesartan in Heart Failure with Preserved Ejection Fraction; LIFE, Losartan Intervention for Endpoint Reduction in Hypertension; LV, left ventricular; MI, myocardial infarction; NAVIGATOR, Nateglinide and Valsartan in Impaired Glucose Tolerance Outcomes Research; ONTARGET, Ongoing Telmisartan Alone and in Combination with Ramipril Global Endpoint Trial; OPTIMAAL, Optimal Trial in Myocardial Infarction with the Angiotensin II Antagonist Losartan; PROFESS, Prevention Regimen for Effectively Avoiding Second Strokes; RENAAL, Reduction of Endpoints in NIDDM with the Angiotensin II Antagonist Losartan; SCOPE, Study on Cognition and Prognosis in the Elderly; TRANSCEND, Telmisartan Randomized Assessment Study in ACE Intolerant Subjects with Cardiovascular Disease; VALIANT, Valsartan in Acute Myocardial Infarction; VALUE, Valsartan Antihypertensive Long-Term Use Evaluation. 
in patients treated with ARBs. Eight landmark, randomized clinical trials involving ARBs have been completed since 2004. None of these trials has shown a statistically significant increase in the incidence of myocardial infarction associated with ARBs compared with placebo or non-ARB active comparators; however, one study (Efficacy of Candesartan on Outcome in Saitama Trial [E-COST] $)^{41}$ in Japanese patients with essential hypertension reported a statistically significant decrease in the risk of myocardial infarction associated with candesartan compared with conventional therapy (relative risk [RR]: 0.44; 95\% CI: $0.21-0.84 ; P<0.05$ ).

In the Ongoing Telmisartan Alone and in Combination With Ramipril Global Endpoint Trial (ONTARGET) study, ${ }^{42}$ which enrolled patients with vascular disease or high-risk diabetes, the RR for fatal or nonfatal myocardial infarction was 1.07 (95\% CI: 0.94-1.22) for telmisartan compared with the ACE inhibitor ramipril. The RR for myocardial infarction for combination therapy with telmisartan and ramipril vs ramipril alone was 1.08 (95\% CI: 0.94-1.23). ${ }^{42}$ In the Telmisartan Randomized Assessment Study in ACE Intolerant Subjects With Cardiovascular Disease (TRANSCEND) study, ${ }^{43}$ which also included patients with diabetes with end-organ damage, the incidence of myocardial infarction was 3.9\% (116/2954) in patients treated with telmisartan and 5.0\% (147/2972) in patients who received placebo (hazard ratio [HR] for telmisartan vs placebo, $0.79 ; 95 \% \mathrm{CI}: 0.62-1.01 ; P=0.059) .{ }^{43}$ Results of the Nateglinide And Valsartan in Impaired Glucose Tolerance Outcomes Research (NAVIGATOR) study ${ }^{44}$ showed that the event rate for fatal or nonfatal myocardial infarction was not significantly different for valsartan compared with placebo in patients with impaired glucose tolerance and cardiovascular disease or cardiovascular risk factors (HR: 0.97; 95\% CI: 0.77-1.23; 1-sided $P=0.41$; 2 -sided $P=0.83)$. In the KYOTO HEART study, ${ }^{45}$ in Japanese patients with uncontrolled hypertension, the HR for acute myocardial infarction for valsartan compared with non-ARB antihypertensive treatment was 0.65 (95\% CI: $0.2-1.8 ; P=0.39)$. Results from the Jikei Heart Study ${ }^{46}$ in Japanese patients with hypertension, coronary heart disease, and/or heart failure showed a HR for new or recurrent acute myocardial infarction of 0.90 (95\% CI: $0.47-1.74 ; P=0.75)$ for valsartan compared with non-ARB therapy.

The Irbesartan in Heart Failure With Preserved Systolic Function (I-PRESERVE) ${ }^{47}$ and Prevention Regimen for Effectively Avoiding Second Strokes (PROFESS) ${ }^{48}$ studies did not report statistical analyses for the difference in the incidence of myocardial infarction between ARBs (irbesartan and telmisartan, respectively) and placebo; however, the incidences of myocardial infarction were numerically similar between the ARBs and placebo (Table 3), and no significant differences were observed in the HR for death from cardiovascular causes. In the I-PRESERVE study, ${ }^{47}$ the HR for death from a cardiovascular cause or nonfatal myocardial infarction or stroke was 0.99 (95\% CI: $0.86-1.13 ; P=0.84)$ for irbesartan vs placebo, and in the PROFESS study, ${ }^{48}$ the HR for death from cardiovascular causes, recurrent stroke, myocardial infarction, or new or worsening heart failure was $0.94(95 \%$ CI: $0.87-1.01 ; P=0.11)$ for telmisartan vs placebo.

Two other landmark randomized clinical trials involving ARBs are not listed in Table 3 because the published results of these studies did not report the incidence of myocardial infarction. The Valsartan Heart Failure Trial (Val-HeFT) study ${ }^{49}$ evaluated the effects of valsartan as add-on therapy to standard treatment for heart failure in patients with NYHA class II, III, or IV heart failure. In this study, treatment with valsartan reduced the incidence of mortality and morbidity (defined as cardiac arrest with resuscitation, hospitalization for heart failure, or receipt of intravenous inotropic or vasodilator therapy for $\geq 4$ hours) by $13.2 \%$ compared with placebo (RR: 0.87; 97.5\% CI: 0.77-0.97; $P=0.009)$. Results of the Morbidity and Mortality After Stroke, Eprosartan Compared With Nitrendipine for Secondary Prevention (MOSES) trial ${ }^{50}$ showed that the incidence density ratio for cardiovascular events (including myocardial infarction and new cardiac failure) over a mean follow-up time of 2.5 years was lower for eprosartan compared with the calcium-channel blocker nitrendipine $(0.75$; 95\% CI: $0.55-1.02 ; P=0.06)$ in patients with hypertension and history of stroke.

\section{ARBs and cancer}

A possible link between an increased incidence of cancer and the use of antihypertensive drugs, including $\beta$-blockers, calcium-channel blockers, diuretics, and the alkaloid reserpine, has been suggested by several studies. ${ }^{9}$ However, the majority of these possible associations remain unproven or highly uncertain. ${ }^{9}$

Results from animal studies have suggested a possible biological mechanism by which ARBs could increase tumor cell proliferation and angiogenesis through selective blockade of $\mathrm{AT}_{1}$ receptors. ${ }^{51}$ This selective blockade results in increased stimulation of $\mathrm{AT}_{2}$ receptors by angiotensin II. Studies in mice ${ }^{52,53}$ have shown that $\mathrm{AT}_{2}$-receptor blockade and gene deletion is associated with decreased expression of pro-angiogenic vascular endothelial growth factor and increased expression of thrombospondin-1. 
A recent meta-analysis by Sipahi and colleagues ${ }^{13}$ found a modestly increased risk of cancer associated with ARBs. Based on an analysis of 5 randomized controlled trials that had a follow-up of at least 1 year, the risk of developing new cancer was $7.2 \%$ (2510/35015) among patients treated with ARBs, compared with 6.0\% (1602/26575) for controls (RR: $1.08 ; 95 \%$ CI: $1.01-1.15 ; P=0.016)$. In the trials included in this analysis, telmisartan was the study drug for $85.7 \%$ $(n=30014)$ of patients who received an ARB. Analysis of the trials involving telmisartan showed that the RR for development of new cancer in patients treated with telmisartan compared with controls was 1.07 (95\% CI: 1.00-1.14; $P=0.05)$.

The authors ${ }^{13}$ also analyzed the results of 5 trials $(\mathrm{N}=68$ 402) for the occurrence of common types of solid organ cancers (ie, breast, lung, and prostate cancer); these results are summarized in Table 4. New lung cancer occurred more frequently in patients treated with ARBs $(0.9 \%$ [361/38 422]) than in control groups (0.7\% [195/29 980]; RR: 1.25 ; 95\% CI: $1.05-1.49 ; P=0.01)$; no significant differences were observed for prostate or breast cancers. Based on the results of 8 trials that reported cancer deaths, no significant difference was observed between ARBs and controls in the incidence of cancer deaths $(1.8 \%[\mathrm{n}=959 / 53424]$ for ARBs vs $1.6 \%$ [n $=639 / 40$ 091] for controls; RR: $1.07 ; 95 \% \mathrm{CI}$ : $0.97-1.18 ; P=0.183$ ).

In addition to the limitations of meta-analyses discussed previously, ${ }^{40}$ there are several limitations specific to the metaanalysis performed by Sipahi and colleagues ${ }^{13}$ that should be considered when interpreting these results. The duration of follow-up in the trials included in this meta-analysis ranged from 1.9-4.8 years. Because cancer is a relatively rare occurrence in any time period of less than 5 years, it has been argued that the duration of follow-up in these trials was too short to draw any meaningful conclusions about the development of new cancers. ${ }^{54}$ In addition, development of cancer is a relatively rare $\mathrm{AE}$, and rare $\mathrm{AEs}$ are often not analyzed statistically in randomized clinical trials because of small sample sizes; this problem can persist even when data are pooled ${ }^{40}$ It is also important to note that these results are based on post-hoc analyses, and the primary studies were not designed to test for the development of cancer. ${ }^{13}$ Further, it is not appropriate to draw conclusions about a possible class effect for all ARBs based on results of this metaanalysis because telmisartan was the study drug in $85.7 \%$ of patients who received ARBs. Because the different ARBs have unique pharmacologic and dosing properties,${ }^{20}$ results heavily weighted for telmisartan cannot be extrapolated to the entire class of medications. As noted by Sipahi and colleagues, publication bias was also a significant limiting factor in this meta-analysis. There is a lack of published and/ or publicly available information on the incidence of cancer observed in clinical trials of ARBs. ${ }^{20}$ Specifically, many large trials (eg, VALUE, ${ }^{29}$ Study on Cognition and Prognosis in the Elderly [SCOPE] ${ }^{55}$ ) did not collect cancer data or did not provide their cancer data to the authors of this study; of 60 trials identified as meeting the inclusion criteria for this analysis, data on cancer incidence and/or cancer deaths were only available from nine trials. ${ }^{13}$ In addition, the authors of this meta-analysis did not have access to patient-level data to determine whether factors such as age, sex, and smoking status may have influenced the results. ${ }^{13}$

Subsequently, a second meta-analysis ${ }^{56}$ was performed to assess whether there is an increased risk of cancer associated with antihypertensive therapy. Results of this analysis ${ }^{56}$ refuted the results of the Sipahi study. ${ }^{13}$ In their meta-analysis, Bangalore and colleagues identified 70 randomized clinical trials of antihypertensive agents (ARBs, ACE inhibitors, calcium-channel blockers, and diuretics) involving 324,168 patients and found no increased risk of cancer associated with ARBs compared with placebo or other antihypertensive controls using random-effects and fixed-effect models (Table 5) ${ }^{56}$ However, in a fixed-effect model, the combination of ARBs with ACE inhibitors was associated with an increased cancer risk compared with placebo and compared with ARBs (Table 5). When the results of individual trials of ARBs were evaluated for cancer risk and cancer-related death, ARBs did not differ significantly vs comparators (Figure 2). In addition, results did not differ for telmisartan compared with other ARBs.

A third meta-analysis,${ }^{57}$ conducted by the ARB Trialists Collaboration, evaluated the incidence of cancer in 15 long-term, randomized, controlled trials that involved 138,769 patients at high risk for cardiovascular disease who received ARBs (telmisartan, irbesartan, valsartan, candesartan, or losartan). In this analysis, the trials included were required to have an average follow-up time of at least 12 months. Similar to the Bangalore meta-analysis, ${ }^{56}$ no increased risk of cancer with ARBs was identified; the cancer incidence in the 15 trials was $6.16 \%(4549 / 73,808)$ in the ARB groups vs $6.31 \%(3856 / 61$ $106)$ in the control groups (odds ratio [OR]: $1.00 ; 95 \% \mathrm{CI}$ : 0.95-1.04; $P=0.886$ ). In addition, no increased cancer risk was observed when evaluating the individual ARBs, and no differences were observed in the incidences of lung, prostate, or breast cancers between ARBs and controls. This analysis also examined cancer risk of $\mathrm{ARB} / \mathrm{ACE}$ inhibitor combinations 
Table 4 Incidence of solid organ cancers reported in a meta-analysis of randomized controlled trials of ARBs

\begin{tabular}{|c|c|c|c|c|c|}
\hline Cancer type & ARB & Control & $\mathbf{R R}(95 \% \mathrm{Cl})$ & $I^{2}$ & $P$ value \\
\hline \multicolumn{6}{|l|}{ Lung cancer } \\
\hline \multicolumn{6}{|l|}{ All available trials } \\
\hline LIFE & $29 / 4605(0.6 \%)$ & $12 / 4588(0.3 \%)$ & $2.4 I(I .23-4.7 I)$ & & 0.01 \\
\hline CHARM-Overall & $31 / 3803(0.8 \%)$ & $25 / 3796(0.7 \%)$ & $1.24(0.73-2.09)$ & & 0.43 \\
\hline TRANSCEND & $35 / 2954(1.2 \%)$ & $27 / 2972(0.9 \%)$ & $1.30(0.79-2.15)$ & & 0.30 \\
\hline ONTARGET & $229 / 17044(1.3 \%)$ & $101 / 8576(1.2 \%)$ & $\mathrm{I} .14(0.90-1.44)$ & & 0.27 \\
\hline PROFESS & $37 / 10016(0.4 \%)$ & $30 / 10048(0.3 \%)$ & $1.24(0.77-2.00)$ & & 0.39 \\
\hline Meta-analysis & $361 / 38422(0.9 \%)$ & $195 / 29980(0.7 \%)$ & $1.25(1.05-1.49)$ & $6.6 \%$ & 0.01 \\
\hline \multicolumn{6}{|l|}{ With background ACE-inhibitor treatment } \\
\hline CHARM-Added & $12 / 1276(0.9 \%)$ & $7 / 1272(0.6 \%)$ & I.7I (0.68-4.33) & & 0.26 \\
\hline ONTARGET (telmisartan + ramipril vs ramipril) & $129 / 8502(1.5 \%)$ & $101 / 8576(1.2 \%)$ & $1.29(0.99-1.67)$ & & 0.055 \\
\hline Meta-analysis & $141 / 9778(1.4 \%)$ & $108 / 9848(1.1 \%)$ & $1.32(1.03-1.69)$ & $0 \%$ & 0.031 \\
\hline \multicolumn{6}{|l|}{ Without background ACE-inhibitor treatment } \\
\hline LIFE & $29 / 4605(0.6 \%)$ & $12 / 4588(0.3 \%)$ & $2.4 I(\mid .23-4.7 I)$ & & 0.01 \\
\hline TRANSCEND & $35 / 2954(1.2 \%)$ & $27 / 2972(0.9 \%)$ & $1.30(0.79-2.15)$ & & 0.30 \\
\hline ONTARGET (telmisartan vs ramipril) & $100 / 8542(1.2 \%)$ & $101 / 8576(1.2 \%)$ & $0.99(0.76-1.31)$ & & 0.97 \\
\hline CHARM-Alternative & $10 / 1013(1.0 \%)$ & $3 / 1015(0.3 \%)$ & $3.34(0.93-12.10)$ & & 0.066 \\
\hline Meta-analysis & $174 / 17$ II 4 (I.0\%) & $|43 / 17| 5 \mid(0.8 \%)$ & $1.50(0.93-2.41)$ & $65 \%$ & 0.097 \\
\hline \multicolumn{6}{|l|}{ Prostate cancer* } \\
\hline \multicolumn{6}{|l|}{ All available trials } \\
\hline LIFE & $58 / 2118(2.7 \%)$ & $42 / 2112(2.0 \%)$ & $1.38(0.93-2.04)$ & & 0.11 \\
\hline CHARM-Overall & $32 / 2617(1.2 \%)$ & $27 / 2582(1.0 \%)$ & $1.17(0.70-1.95)$ & & 0.55 \\
\hline TRANSCEND & $35 / 1674(2.1 \%)$ & $27 / 1705(1.6 \%)$ & $1.32(0.80-2.17)$ & & 0.27 \\
\hline ONTARGET & $275 / 12544(2.2 \%)$ & $128 / 6245(2.0 \%)$ & $\mathrm{I} .07(0.87-1.32)$ & & 0.53 \\
\hline PROFESS & $36 / 6455(0.6 \%)$ & $32 / 6418(0.5 \%)$ & $1.12(0.70-1.80)$ & & 0.64 \\
\hline Meta-analysis & $436 / 25408(1.7 \%)$ & $256 / 19062(1.3 \%)$ & I.I5 (0.99-I.34) & $0 \%$ & 0.076 \\
\hline \multicolumn{6}{|l|}{ With background ACE-inhibitor treatment } \\
\hline CHARM-Added & $7 / 1006(0.7 \%)$ & $9 / 1000(0.9 \%)$ & $0.77(0.29-2.07)$ & & 0.61 \\
\hline ONTARGET (telmisartan + ramipril vs ramipril) & $14 \mid / 6252(2.3 \%)$ & $128 / 6245(2.0 \%)$ & $1.10(0.87-1.39)$ & & 0.43 \\
\hline Meta-analysis & $148 / 7258(2.0 \%)$ & | $37 / 7245$ (1.9\%) & $1.08(0.86-1.36)$ & $0 \%$ & 0.52 \\
\hline \multicolumn{6}{|l|}{ Without background ACE-inhibitor treatment } \\
\hline LIFE & $58 / 2118(2.7 \%)$ & $42 / 2112(2.0 \%)$ & $1.38(0.93-2.04)$ & & 0.11 \\
\hline TRANSCEND & $35 / 1674(2.1 \%)$ & $27 / 1705(1.6 \%)$ & $1.32(0.80-2.17)$ & & 0.27 \\
\hline ONTARGET (telmisartan vs ramipril) & $134 / 6292(2.1 \%)$ & $128 / 6245(2.0 \%)$ & $1.04(0.82-1.32)$ & & 0.75 \\
\hline CHARM-Alternative & $8 / 691(1.2 \%)$ & $3 / 691(0.4 \%)$ & $2.67(0.71-10.01)$ & & 0.15 \\
\hline Meta-analysis & $235 / 10775(2.2 \%)$ & $200 / 10753(1.9 \%)$ & $1.17(0.97-1.41)$ & $9.6 \%$ & 0.10 \\
\hline \multicolumn{6}{|l|}{ Breast cancer ${ }^{\dagger}$} \\
\hline \multicolumn{6}{|l|}{ All available trials } \\
\hline LIFE & $37 / 2487$ (1.5\%) & $36 / 2476(1.5 \%)$ & $\mathrm{I} .02(0.65-1.6 \mathrm{I})$ & & 0.92 \\
\hline CHARM-Overall & $17 / 1186(1.4 \%)$ & $17 / 1214(1.4 \%)$ & $1.02(0.52-2.00)$ & & 0.95 \\
\hline TRANSCEND & $20 / 1280(1.6 \%)$ & $17 / 1267(1.3 \%)$ & $1.16(0.6 \mathrm{I}-2.2 \mathrm{I})$ & & 0.64 \\
\hline ONTARGET & $60 / 4500(1.3 \%)$ & $34 / 2331(1.5 \%)$ & $0.91(0.60-1.39)$ & & 0.67 \\
\hline PROFESS & $20 / 356 \mathrm{I}(0.6 \%)$ & $15 / 3630(0.4 \%)$ & $1.36(0.70-2.65)$ & & 0.37 \\
\hline Meta-analysis & $154 / 13014(1.2 \%)$ & $119 / 10918(1.1 \%)$ & $1.04(0.82-1.32)$ & $0 \%$ & 0.74 \\
\hline \multicolumn{6}{|l|}{ With background ACE-inhibitor treatment ${ }^{\ddagger}$} \\
\hline ONTARGET (telmisartan + ramipril vs ramipril) & $33 / 2250(1.5 \%)$ & $34 / 2331$ (1.5\%) & $1.00(0.6 \mathrm{I}-\mathrm{I} .66)$ & & $>0.99$ \\
\hline \multicolumn{6}{|l|}{ Without background ACE-inhibitor treatment } \\
\hline LIFE & $37 / 2487(1.5 \%)$ & $36 / 2476(1.5 \%)$ & $\mathrm{I} .02(0.65-1.6 \mathrm{I})$ & & 0.92 \\
\hline TRANSCEND & $20 / 1280(1.6 \%)$ & $17 / 1267(1.3 \%)$ & $1.16(0.6 \mathrm{I}-2.2 \mathrm{I})$ & & 0.64 \\
\hline ONTARGET (telmisartan vs ramipril) & $27 / 2250$ (1.2\%) & $34 / 2331$ ( $1.5 \%)$ & $0.83(0.50-1.36)$ & & 0.45 \\
\hline CHARM-Alternative & $5 / 322(1.6 \%)$ & $4 / 324(1.2 \%)$ & $1.26(0.34-4.64)$ & & 0.73 \\
\hline Meta-analysis & $89 / 6339(1.2 \%)$ & $91 / 6398(1.4 \%)$ & $0.99(0.74-1.32)$ & $0 \%$ & 0.93 \\
\hline
\end{tabular}

Reprinted from The Lancet Oncology, volume II, issue 7, Sipahi et al, 'Angiotensin-receptor blockade and risk of cancer: meta-analysis of randomised controlled trials', PP 627-636, Copyright 2010, with permission from Elsevier..$^{13}$

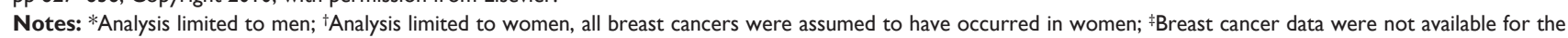
CHARM-Added trial.

Abbreviations: ACE, angiotensin-converting enzyme; ARB, angiotensin-receptor blocker; CHARM, Candesartan in Heart Failure Assessment in Reduction of Mortality; $\mathrm{Cl}$, confidence interval; LIFE, Losartan Intervention for Endpoint Reduction in Hypertension; ONTARGET, Ongoing Telmisartan Alone and in Combination with Ramipril Global Endpoint Trial; PROFESS, Prevention Regimen for Effectively Avoiding Second Strokes; RR, risk ratio; TRANSCEND, Telmisartan Randomized Assessment Study in ACE Intolerant Subjects with Cardiovascular Disease. 
Table 5 Risk of cancer and cancer-related death with ARBs

\begin{tabular}{|c|c|c|c|c|c|c|}
\hline \multirow[t]{2}{*}{ Comparator } & \multicolumn{3}{|c|}{ Cancer odds ratios, $95 \% \mathrm{Cl}$} & \multicolumn{3}{|c|}{ Cancer-related death odds ratios, $95 \% \mathrm{Cl}$} \\
\hline & $\begin{array}{l}\text { Direct } \\
\text { comparison } \\
\text { (Peto OR) }\end{array}$ & $\begin{array}{l}\text { Multiple } \\
\text { comparisons } \\
\text { (fixed effect) }\end{array}$ & $\begin{array}{l}\text { Multiple } \\
\text { comparisons } \\
\text { (random effects) }\end{array}$ & $\begin{array}{l}\text { Direct } \\
\text { comparison } \\
\text { (Peto OR) }\end{array}$ & $\begin{array}{l}\text { Multiple } \\
\text { comparisons } \\
\text { (fixed effect) }\end{array}$ & $\begin{array}{l}\text { Multiple } \\
\text { comparisons } \\
\text { (random effects) }\end{array}$ \\
\hline ACEis & $0.96(0.86-1.06)$ & $0.99(0.92-1.07)$ & $0.99(0.84-1.09)$ & $0.97(0.83-1.14)$ & $0.95(0.83-1.07)$ & $0.93(0.80-1.08)$ \\
\hline$\beta$ Blockers & $0.89(0.76-1.04)$ & $0.96(0.88-1.05)$ & $0.96(0.82-1.08)$ & $0.97(0.74-1.26)$ & $0.93(0.80-1.08)$ & $0.97(0.80-1.19)$ \\
\hline CCBs & $1.18(1.04-1.33)$ & $1.04(0.96-1.11)$ & $1.03(0.92-1.16)$ & $1.19(0.40-3.56)$ & $0.96(0.82-1.10)$ & $0.96(0.78-1.16)$ \\
\hline Diuretics & $1.01(0.06-16.67)$ & $0.99(0.90-1.09)$ & $0.98(0.82-1.25)$ & - & $0.98(0.84-1.13)$ & $0.97(0.78-1.17)$ \\
\hline Controls & $1.05(0.76-1.47)$ & $0.96(0.74-1.22)$ & $0.96(0.70-1.37)$ & $1.30(0.75-2.27)$ & $1.08(0.79-1.44)$ & $\mathrm{I} .08(0.8 \mathrm{I}-\mathrm{I} .40)$ \\
\hline ACEis + ARBs & $1.10(0.99-1.22)$ & $1.13(1.03-1.24)$ & $1.14(0.93-1.33)$ & $1.07(0.90-1.27)$ & $1.09(0.94-1.27)$ & $1.06(0.87-1.30)$ \\
\hline
\end{tabular}

Reprinted from The Lancet Oncology, volume 12, issue I, Bangalore et al, 'Antihypertensive drugs and risk of cancer: network meta-analyses and trial sequential analyses of 324 I68 participants from randomised trials', pp 65-82, Copyright 20II, with permission from Elsevier. ${ }^{56}$

Abbreviations: $\mathrm{ACEi}$, angiotensin-converting enzyme inhibitor; $\mathrm{ARB}$, angiotensin II receptor blocker; $\mathrm{CCB}$, calcium-channel blocker; $\mathrm{Cl}$, confidence interval; OR, odds ratio.

vs $\mathrm{ACE}$ inhibitors alone, $\mathrm{ARBs}$ alone vs $\mathrm{ACE}$ inhibitors alone, and ARBs vs placebo/controls without ACE inhibitors. No increased risk of cancer was observed in any of these overall comparisons (Figure 3). A nominal increase in cancer risk was observed with the $\mathrm{ARB} / \mathrm{ACE}$ inhibitor combination in one trial (ONTARGET) but a reduced cancer risk was observed with this combination in another (VALIANT). Thus, the authors concluded that the increased risk of cancer observed with the ARB/ACE inhibitor combination may be due to chance and that further study is needed to resolve this question.

Because cancer was not a prespecified outcome in most randomized clinical trials involving ARBs, the amount of published information discussing cancer rates in individual randomized clinical trial results is limited. The authors of both the Sipahi ${ }^{13}$ and Bangalore ${ }^{56}$ studies searched FDA dockets for information on cancer submitted to the FDA during drug approval processes, labeling changes, and FDA meeting minutes. The authors of the Bangalore study ${ }^{56}$ also contacted authors and study investigators via email to obtain additional unpublished cancer data. The authors of the ARB Trialists analysis ${ }^{57}$ had access to individual data for several studies with prespecified methods for cancer identification and tabulated cancer outcomes data for the other trials.

The Bangalore ${ }^{56}$ and ARB Trialists ${ }^{57}$ meta-analyses were more robust than the Sipahi meta-analysis ${ }^{13}$ because more trials were included and multiple comparison analysis was performed on the network of different treatments. However, the authors of the Bangalore study ${ }^{56}$ acknowledge several limitations including the possibility that the survival benefit associated with antihypertensive therapy compared with placebo may have introduced a "survival bias" that increased the incidence of cancer in active treatment groups. For all the meta-analyses, there may have been other confounding variables that are nearly impossible to measure, such as exposure to radiation or carcinogens. None took into consideration the incidence of a specific cancer in the general population. In addition, the selection criteria used to include trials in these meta-analyses could have influenced the findings (ie, certain trials when put together could increase, decrease, or have no effect on cancer risk). Moreover, results are limited by the short-term nature of most trials and the relatively short duration of exposure to the drugs in question to determine cancer risk. Finally, publication bias, issues with heterogeneity, and availability of data can affect any meta-analysis.

Several population-based studies have evaluated the association between antihypertensive treatment and cancer over the years. A recent analysis by Huang and colleagues specifically investigated the association between ARBs and the occurrence of new cancers in 109,002 patients with newly diagnosed hypertension. ${ }^{58}$ Patients were identified from a random sample of 1 million individuals of mostly Chinese ethnicity using the Taiwanese National Health Insurance database. Over an average follow-up period of 5.7 years, a total of 9067 cases of new cancer were reported with a significantly lower occurrence among patients receiving ARBs than not receiving ARBs (3082 vs 5985; $P<0.001)$. This was the case after adjusting for age, sex, comorbidities, and medications for hypertension control (HR: 0.66; 95\% CI: 0.63-0.68; $P<0.001$ ). Consistent results were observed regardless of $\mathrm{ARB}$ and for all types of cancer, although conclusions regarding cause and effect cannot be established.

Based on the results of the Sipahi study, the FDA initiated a safety review of ARBs. ${ }^{59}$ In July 2010, the FDA issued a communication stating that their results to date indicated that the benefits of ARB therapy outweighed the risks. The FDA did not conclude that ARBs increase the risk of cancer but they will continue their analysis and update the public as more data become available. 
A

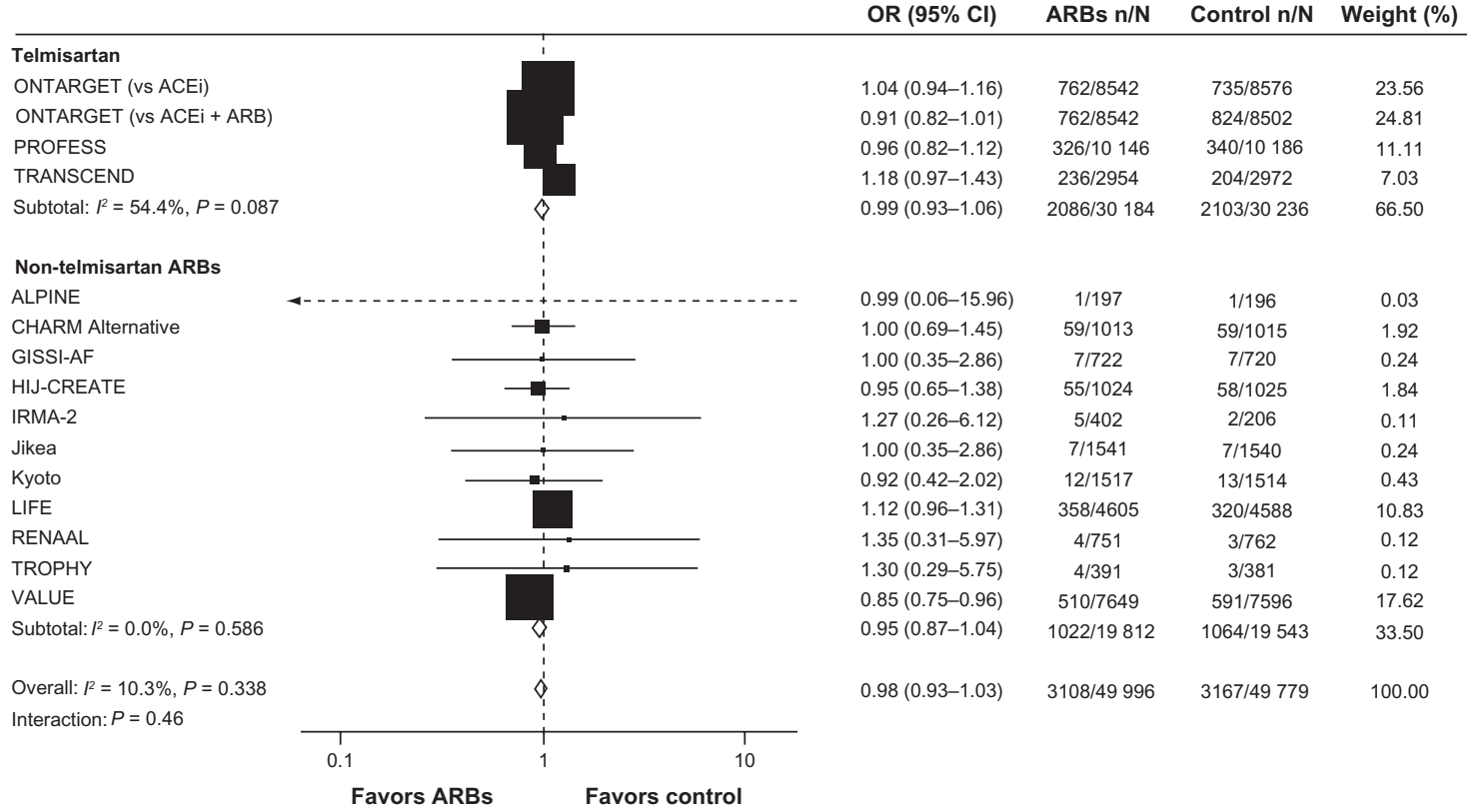

B

OR $(95 \% \mathrm{Cl}) \quad$ ARBs $\mathrm{n} / \mathrm{N} \quad$ Control $\mathrm{n} / \mathrm{N}$ Weight (\%)

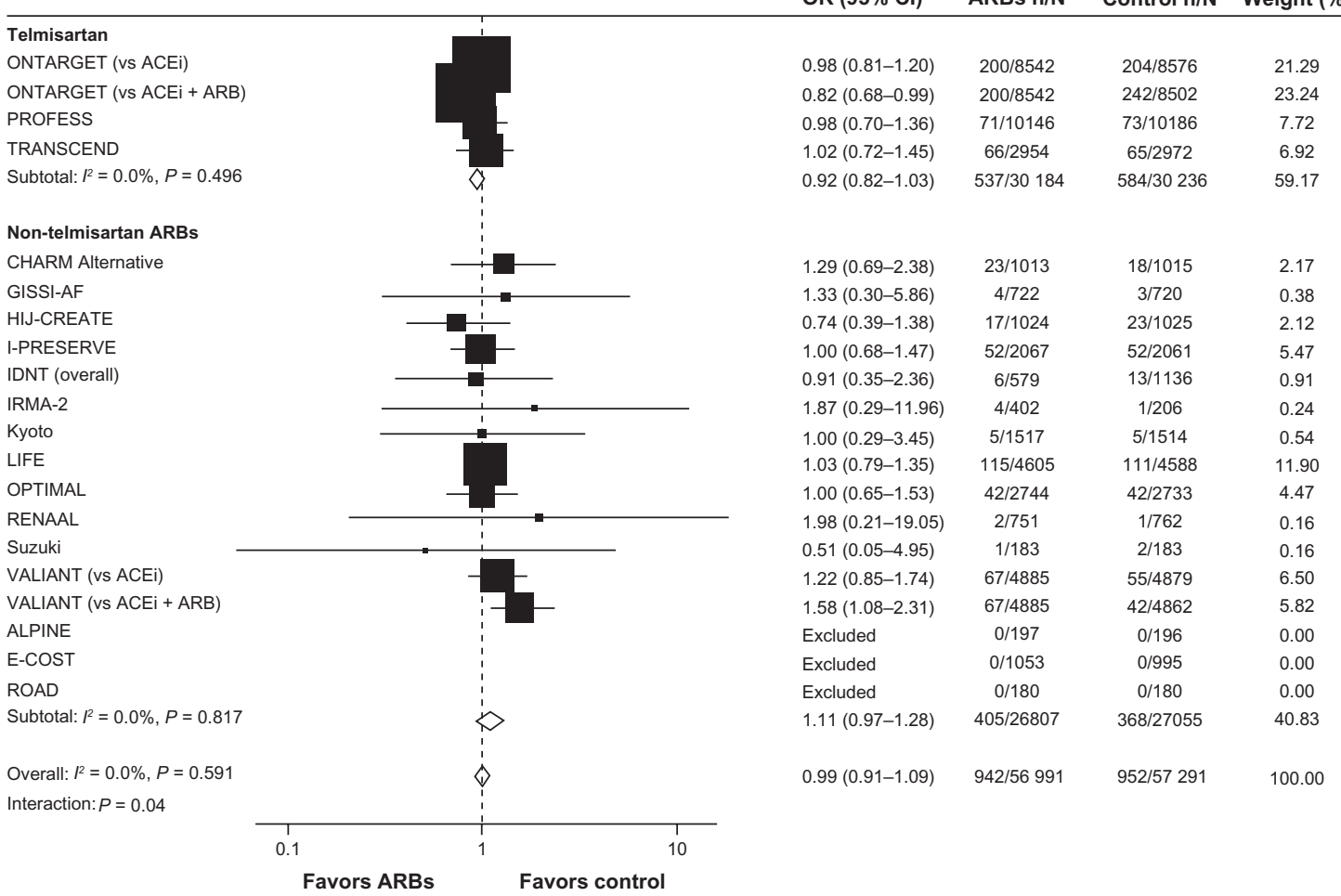

Figure 2 ARBs and cancer risk A) and cancer-related death B), stratified by ARB type (telmisartan or other).

Reprinted from The Lancet Oncology, volume 12, issue I, Bangalore et al, 'Antihypertensive drugs and risk of cancer: network meta-analyses and trial sequential analyses of 324168 participants from randomised trials', PP 65-82, Copyright 20II, with permission from Elsevier. ${ }^{56}$

Note: The size of the data marker represents the weight of each trial. CHARM-added and Val-HeFT trials were excluded because they were regarded as ACEi and ARB combination trials.

Abbreviations: ACEi, angiotensin-converting enzyme inhibitor; ALPINE, Antihypertensive Treatment and Lipid Profile in a North of Sweden Efficacy Evaluation; ARBs, angiotensin receptor blockers; CHARM, Candesartan in Heart failure Assessment in Reduction of Mortality; Cl, confidence interval; E-COST, Efficacy of Candesartan on Outcome in Saitama Trial; GISSI-AF, Gruppo Italiano per lo Studio della Sopravvivenza nell'Infarto Miocardico-Atrial Fibrillation; HIJ-CREATE, Heart Institute of Japan Candesartan Randomized Trial for Evaluation in Coronary Artery Disease; IDNT, Irbesartan Diabetic Nephropathy Trial; I-PRESERVE, Irbesartan in Heart Failure With Preserved Systolic Function; IRMA-2, Irbesartan in Microalbuminuria, Type 2 Diabetic Nephropathy Trial; LIFE, Losartan Intervention For Endpoint Reduction in Hypertension; OPTIMAL, Optimal Trial In Myocardial Infarction With the Angiotensin Receptor Blocker Losartan; ONTARGET, Ongoing Telmisartan Alone and in Combination With Ramipril Global Endpoint Trial; OR, odds ratio; PROFESS, The Prevention Regimen For Effectively Avoiding Second Strokes Trial; RENAAL, Reduction of Endpoints in Non-insulin-dependent Diabetes Mellitus With Angiotensin II Antagonist Losartan; ROAD, Renoprotection of Optimal Antiproteinuric Doses; TRANSCEND, Telmisartan Randomized Assessment Study in ACE Intolerant Subjects With Cardiovascular Disease; TROPHY, Trial of Prevention of Hypertension; VALIANT, Valsartan in Acute Myocardial Infarction; VALUE, Valsartan Antihypertensive Long-Term Use Evaluation. 


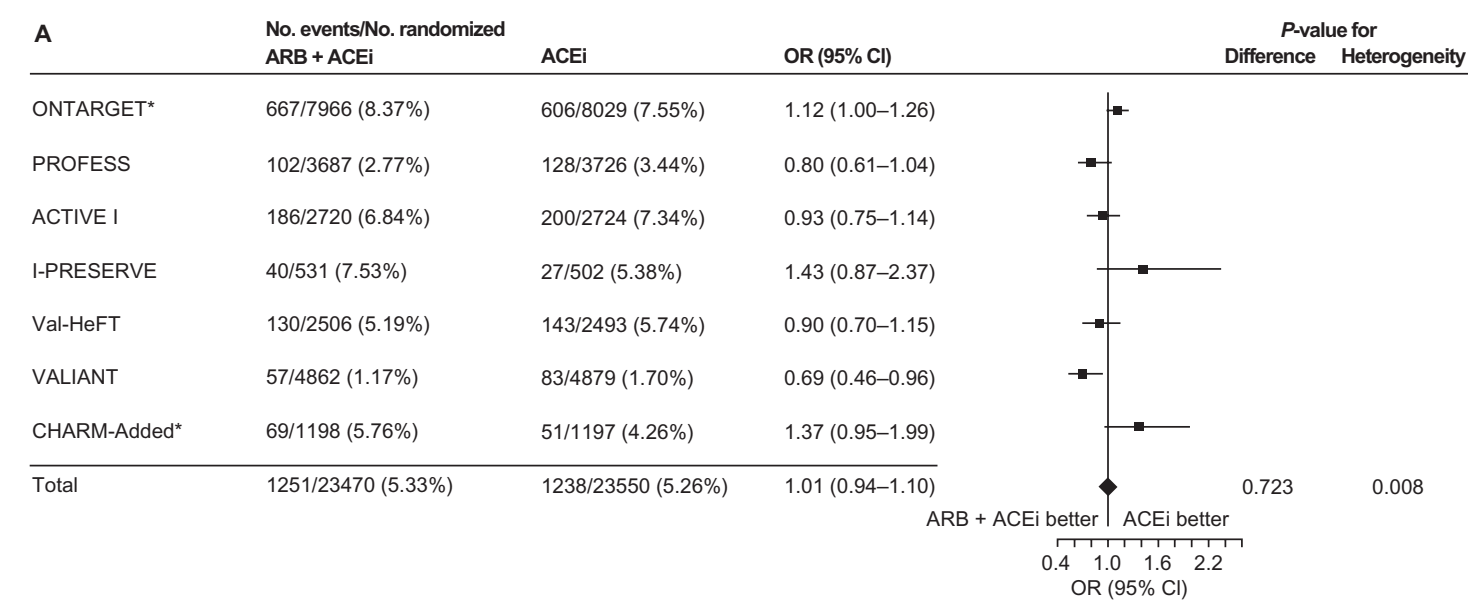

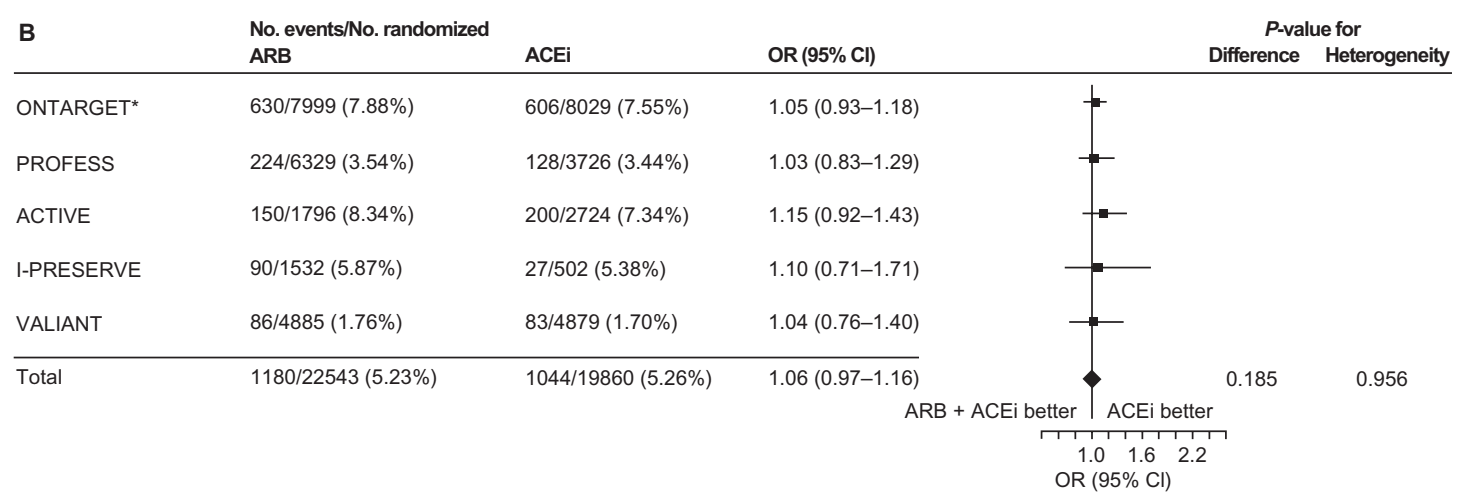

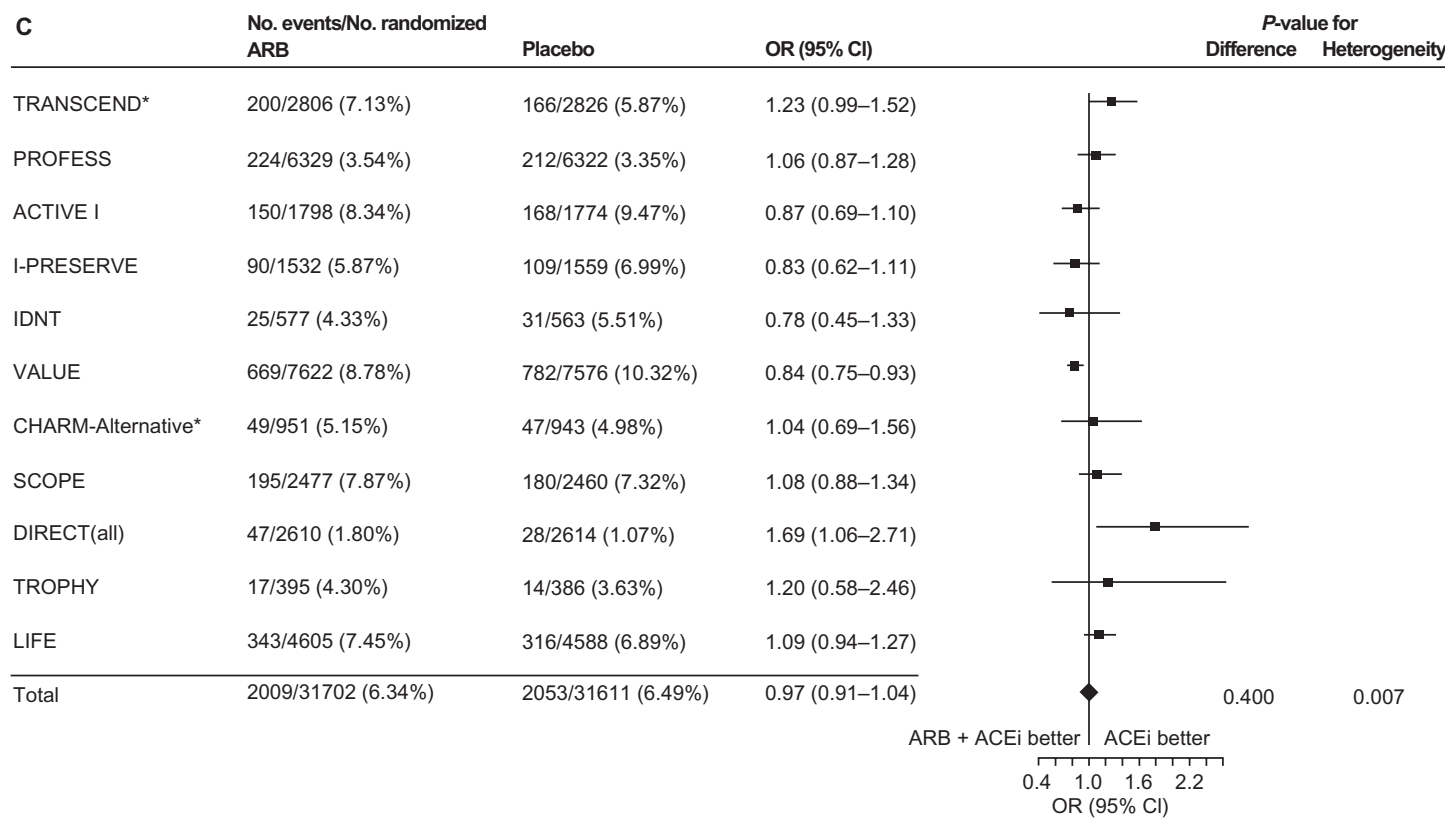

Figure 3 Incidence of cancer with A) ARB/ACE inhibitor combination vs ACE inhibitor alone, B) ARB alone vs ACE inhibitor alone, and C) ARB vs placebo/control with no ACE inhibitor.

Reprinted from the Journal of Hypertension, volume 29, issue 4, the ARB trialists collaboration, 'Effects of telmisartan, irbesartan, candesartan, and losartan on cancers in I5 trials enrolling 138769 individuals', pP 623-635, Copyright 20II, with permission from Wolters Kluwer Health. ${ }^{57}$

Notes: In the LIFE study, atenolol was the control. "Included patients who were free of cancer at baseline.

Abbreviations: ACEi, angiotensin-converting enzyme inhibitor; ACTIVE, Atrial Fibrillation Clopidogrel Trial With Irbesartan for Prevention of Vascular Events; ARB, angiotensin receptor blocker; CHARM, Candesartan in Heart failure Assessment in Reduction of Mortality; Cl, confidence interval; DIRECT, Diabetic Retinopathy Candesartan Trials; IDNT, Irbesartan in Diabetic Nephropathy Trial; I-PRESERVE, Irbesartan in Heart Failure With Preserved Systolic Function; LIFE, Losartan Intervention For Endpoint Reduction in Hypertension; ONTARGET, Ongoing Telmisartan Alone and in Combination with Ramipril Global Endpoint Trial; OR, odds ratio; PROFESS, The Prevention Regimen for Effectively Avoiding Second Strokes Trial; SCOPE, Study on Cognition and Prognosis in the Elderly; TRANSCEND, Telmisartan Randomized Assessment Study in ACE Intolerant Subjects With Cardiovascular Disease; TROPHY, Trial of Prevention of Hypertension; Val-HeFT, Valsartan Heart Failure Trial; VALIANT, Valsartan in Acute Myocardial Infarction; VALUE, Valsartan Antihypertensive Long-Term Use Evaluation. 
Table 6 Adverse events of special interest from randomized controlled trials of aliskiren

\begin{tabular}{|c|c|c|c|c|c|c|c|}
\hline \multicolumn{8}{|c|}{ A. Short-term placebo-controlled studies } \\
\hline $\begin{array}{l}\text { Adverse event } \\
\text { of special interest }\end{array}$ & $\begin{array}{l}\text { Placebo } \\
n=1555\end{array}$ & $\begin{array}{l}\text { Aliskiren } \\
\text { I } 50 \mathrm{mg} \\
\mathrm{n}=1246\end{array}$ & $\begin{array}{l}\text { Aliskiren } \\
300 \mathrm{mg} \\
\mathrm{n}=1363\end{array}$ & $\begin{array}{l}\text { Aliskiren/ } \\
\text { HCTZ } \\
n=1464\end{array}$ & $\begin{array}{l}\text { HCT } \\
n=555\end{array}$ & $\begin{array}{l}\text { Aliskiren/ } \\
\text { ARB } \\
n=624\end{array}$ & $\begin{array}{l}\text { ARB } \\
n=1069\end{array}$ \\
\hline Angioedema/urticaria & $8(0.5)$ & $2(0.2)$ & $4(0.3)$ & $\mathrm{I}(0.1)$ & $\mathrm{I}(0.2)$ & 0 & $3(0.3)$ \\
\hline Cough & II (0.7) & $18(1.4)$ & $10(0.7)$ & $20(1.4)$ & $4(0.7)$ & $3(0.5)$ & $4(0.4)$ \\
\hline Rash & $6(0.4)$ & $3(0.2)$ & $3(0.2)$ & $3(0.2)$ & $4(0.7)$ & 0 & $\mathrm{I}(0 . \mathrm{l})$ \\
\hline Hypotension & $34(2.2)$ & $16(1.3)$ & $37(2.7)$ & $54(3.7)$ & $19(3.4)$ & $16(2.6)$ & $25(2.3)$ \\
\hline Hyperkalemia & I $(0.1)$ & 0 & I $(0.1)$ & 0 & I (0.2) & 0 & 0 \\
\hline Peripheral edema & $12(0.8)$ & $6(0.5)$ & $18(1.3)$ & $13(0.9)$ & $7(1.3)$ & $\mathrm{I}(0.2)$ & $5(0.5)$ \\
\hline Renal dysfunction & $2(0.1)$ & $7(0.6)$ & $3(0.2)$ & $I(0.1)$ & 0 & $2(0.3)$ & $2(0.2)$ \\
\hline Diarrhea & $19(1.2)$ & $18(1.4)$ & $27(2.0)$ & $24(1.6)$ & $10(1.8)$ & $10(1.6)$ & $17(1.6)$ \\
\hline $\begin{array}{l}\text { Gastrointestinal } \\
\text { bleeding or ulceration }\end{array}$ & $2(0.1)$ & $\mathrm{I}(0 . \mathrm{I})$ & $\mathrm{I}(0 . \mathrm{I})$ & $3(0.2)$ & $I(0.2)$ & $\mathrm{I}(0.2)$ & $\mathrm{I}(0.1)$ \\
\hline \multicolumn{8}{|c|}{ B. Long-term active-controlled studies } \\
\hline $\begin{array}{l}\text { Adverse event of } \\
\text { special interest }\end{array}$ & $\begin{array}{l}\text { Aliskiren alone } \\
\text { (all doses) } \\
\mathrm{n}=1594\end{array}$ & $\begin{array}{l}\text { Aliskiren } \\
\text { I } 50 \mathrm{mg} \\
\mathrm{n}=87 \text { I }\end{array}$ & $\begin{array}{c}\text { Aliskiren } \\
300 \mathrm{mg} \\
\mathrm{n}=723 \\
\end{array}$ & $\begin{array}{l}\text { All aliskiren* } \\
n=I 749\end{array}$ & $\begin{array}{l}\text { ARB } \\
n=154\end{array}$ & $\begin{array}{l}\text { ACEi } \\
n=866\end{array}$ & $\begin{array}{l}\text { HCTZ } \\
n=557\end{array}$ \\
\hline Angioedema/urticaria & $7(0.4)$ & $4(0.5)$ & $3(0.4)$ & $8(0.5)$ & 0 & $4(0.5)$ & $2(0.4)$ \\
\hline Cough & $62(3.9)$ & $38(4.4)$ & $24(3.3)$ & $64(3.7)$ & $3(1.9)$ & $104(12.0)$ & $22(3.9)$ \\
\hline Rash & $14(0.9)$ & $6(0.7)$ & $8(1.1)$ & $15(0.9)$ & $\mathrm{I}(0.6)$ & $4(0.5)$ & $5(0.9)$ \\
\hline Hypotension & $121(7.6)$ & $73(8.4)$ & $48(6.6)$ & $135(7.7)$ & $7(4.5)$ & $79(9.1)$ & $36(6.5)$ \\
\hline Hyperkalemia & $2(0.1)$ & $\mathrm{I}(0 . \mathrm{I})$ & I $(0.1)$ & $2(0.1)$ & $\mathrm{I}(0.6)$ & $2(0.2)$ & 0 \\
\hline Peripheral edema & $76(4.8)$ & $4 \mid(4.7)$ & $35(4.8)$ & $79(4.5)$ & $2(1.3)$ & $34(3.9)$ & $34(6.1)$ \\
\hline Renal dysfunction & $6(0.4)$ & $2(0.2)$ & $4(0.6)$ & $6(0.3)$ & I (0.6) & $3(0.3)$ & $2(0.4)$ \\
\hline Diarrhea & $74(4.6)$ & $52(6.0)$ & $22(3.0)$ & $81(4.6)$ & $9(5.8)$ & $33(3.8)$ & $17(3.1)$ \\
\hline $\begin{array}{l}\text { Gastrointestinal } \\
\text { bleeding or ulceration }\end{array}$ & $3(0.2)$ & $\mathrm{I}(0.1)$ & $2(0.3)$ & $5(0.3)$ & I $(0.6)$ & $2(0.2)$ & $2(0.4)$ \\
\hline
\end{tabular}

Reprinted from the Journal of Clinical Hypertension, volume 12, issue 10, White et al, 'Safety and tolerability of the direct renin inhibitor aliskiren: a pooled analysis of clinical experience in more than 12,000 patients with hypertension', pp 765-775, Copyright 2010, with permission from John Wiley and Sons. ${ }^{16}$

Notes: *“All aliskiren" includes patients who have received aliskiren as monotherapy or in combination with other antihypertensive agents. Data are number (\%) of patients. Data are presented according to the treatment group to which patients were randomized, irrespective of doses used during any titration periods.

Abbreviations: ACEi, angiotensin-converting enzyme inhibitor; ARB, angiotensin receptor blocker; HCTZ, hydrochlorothiazide.

\section{Safety of aliskiren}

The clinical studies conducted to date with aliskiren have shown this agent to be well tolerated with an AE profile similar to that of placebo, although the treatment duration has been too short to evaluate potential risk for myocardial infarction or cancer. The most commonly reported AEs were fatigue, headache, dizziness, diarrhea, nasopharyngitis, and back pain. ${ }^{15}$ Because aliskiren does not inhibit or induce cytochrome $\mathrm{P} 450$ isoenzymes, it has relatively few interactions with other drugs. ${ }^{15}$ Aliskiren is contraindicated for women who are pregnant or may become pregnant because of the risk of fetal and neonatal morbidity and mortality associated with drugs that act on the RAS. ${ }^{60}$

To evaluate the safety and tolerability of aliskiren, White and colleagues pooled safety data from 12 randomized clinical trials of aliskiren involving 12,188 patients with hypertension. ${ }^{16}$ The studies included in this analysis were categorized as short term ( 8 weeks) placebo controlled or long term (26-52 weeks) active controlled. In the short-term studies $(\mathrm{n}=8862)$, AEs were reported by $33.6 \%, 31.6 \%$, and
$36.8 \%$ of patients treated with aliskiren $150 \mathrm{mg}$, aliskiren $300 \mathrm{mg}$, and placebo, respectively. Serious AEs occurred in $0.4 \%, 0.5 \%$, and $0.7 \%$ of patients treated with aliskiren $150 \mathrm{mg}$, aliskiren $300 \mathrm{mg}$, and placebo, respectively. The rate of discontinuation due to AEs was $\leq 1.4 \%$ for both aliskiren doses and $2.6 \%$ for placebo. In the long-term studies ( $\mathrm{n}=3326)$, AEs were reported by $33.7 \%$ of patients treated with aliskiren $150 \mathrm{mg}, 43.2 \%$ of patients treated with aliskiren $300 \mathrm{mg}, 60.1 \%$ of patients treated with ACE inhibitors, $53.9 \%$ of patients treated with ARBs, and $48.9 \%$ of patients treated with thiazide diuretics. Serious AEs occurred in $3.4 \%$ of patients treated with aliskiren (both doses), compared with $2.4 \%, 8.4 \%$, and $1.7 \%$ of patients treated with ACE inhibitors, ARBs, and thiazide diuretics, respectively. The rate of discontinuation due to AEs was $3.2 \%, 1.7 \%, 6.9 \%, 6.5 \%$, and $3.3 \%$ for the aliskiren 150-mg, aliskiren 300-mg, ACE inhibitors, ARBs, and thiazide diuretics groups, respectively. Incidences of AEs of special interest (possibly related to RAS agents) are listed in Table 6. The incidence of cough was low for all aliskiren 
treatment groups; it was similar to that of placebo in the short-term studies and lower than ACE inhibitors in the long-term studies. In the short-term studies, the incidence of abnormalities in prespecified laboratory values was low and similar to placebo. In the aliskiren $150-\mathrm{mg}$, aliskiren $300-\mathrm{mg}$, and placebo groups, respectively, $0.9 \%, 1.6 \%$, and $1.3 \%$ of patients had serum potassium levels $>5.5 \mathrm{mEq} / \mathrm{L}$ at any visit during the double-blind treatment period. In the long-term studies, $5.7 \%$ of patients treated with aliskiren $300 \mathrm{mg}$ had serum potassium levels $>5.5 \mathrm{mEq} / \mathrm{L}$, compared with $1.9 \%$ to $3.7 \%$ of patients in all other treatment groups. Overall, the safety profile of aliskiren was similar to that of placebo and similar or superior to other antihypertensive agents. $^{16}$

\section{Conclusions}

ARBs are well tolerated, with a class safety profile similar to that of placebo and no known class-specific AEs. Results from meta-analyses evaluating the risks of myocardial infarction or cancer associated with ARBs have been inconsistent, and caution should be used when evaluating the results of these analyses because even the most well designed and carefully executed meta-analyses have significant limitations. Evidence from landmark, randomized clinical trials published to date does not suggest a link between ARBs and an increased risk of cancer or myocardial infarction. The FDA's position on ARB use is that the benefits of these drugs outweigh their risks, and the FDA has not concluded that ARBs increase the risk of cancer. The DRI aliskiren is also a well-tolerated antihypertensive drug, with a safety profile that is similar to that of placebo and similar or superior to those of other antihypertensive drugs. As part of the aliskiren ASPIRE HIGHER clinical trials program, studies are ongoing in patients with known cardiovascular or renal risk factors and results of these trials will provide additional data on the overall tolerability profile of aliskiren. ${ }^{1}$

\section{Acknowledgments}

Technical assistance with editing, figure preparation and styling of the manuscript for submission was provided by Cherie Koch, PhD, and Michael S. McNamara, MS, of Oxford PharmaGenesis Inc., and was funded by Novartis Pharmaceuticals Corporation. The author was fully responsible for all content and editorial decisions and received no financial support or other form of compensation related to the development of this manuscript. The opinions expressed in the manuscript are those of the author and Novartis Pharmaceuticals Corporation had no influence on the contents.

\section{Disclosure}

The author declares no conflicts of interest.

\section{References}

1. Fogari R, Zoppi A. New class of agents for treatment of hypertension: focus on direct renin inhibition. Vasc Health Risk Manag. 2010;6: $869-882$.

2. Sever PS, Gradman AH, Azizi M. Managing cardiovascular and renal risk: the potential of direct renin inhibition. J Renin Angiotensin Aldosterone Syst. 2009;10(2):65-76.

3. Volpe M, Savoia C, De Paolis P, Ostrowska B, Tarasi D, Rubattu S. The reninangiotensin system as a risk factor and therapeutic target for cardiovascular and renal disease. JAm Soc Nephrol. 2002;13(Suppl 3):S173-S178.

4. Gullapalli N, Bloch MJ, Basile J. Renin-angiotensin-aldosterone system blockade in high-risk hypertensive patients: current approaches and future trends. Ther Adv Cardiovasc Dis. 2010;4(6):359-373.

5. Chobanian AV, Bakris GL, Black HR, et al. Seventh report of the Joint National Committee on Prevention, Detection, Evaluation, and Treatment of High Blood Pressure. Hypertension. 2003;42(6): $1206-1252$.

6. Karlberg BE. Cough and inhibition of the renin-angiotensin system. J Hypertens. 1993;11(Suppl 3):S49-S52.

7. Dicpinigaitis PV. Angiotensin-converting enzyme inhibitor-induced cough: ACCP evidence-based clinical practice guidelines. Chest. 2006; 129(1 Suppl):169S-173S.

8. Sica DA, Black HR. Angioedema in heart failure: occurrence with ACE inhibitors and safety of angiotensin receptor blocker therapy. Congest Heart Fail. 2002;8(6):334-341, 345.

9. Grossman E, Messerli FH, Goldbourt U. Antihypertensive therapy and the risk of malignancies. Eur Heart J. 2001;22(15):1343-1352.

10. Friis S, Sorensen HT, Mellemkjaer L, et al. Angiotensin-converting enzyme inhibitors and the risk of cancer: a population-based cohort study in Denmark. Cancer. 2001;92(9):2462-2470.

11. Verdecchia P, Angeli F, Repaci S, Mazzotta G, Gentile G, Reboldi G. Comparative assessment of angiotensin receptor blockers in different clinical settings. Vasc Health Risk Manag. 2009;5:939-948.

12. Strauss MH, Hall AS. Angiotensin receptor blockers may increase risk of myocardial infarction: unraveling the ARB-MI paradox. Circulation. 2006;114(8):838-854.

13. Sipahi I, Debanne SM, Rowland DY, Simon DI, Fang JC. Angiotensinreceptor blockade and risk of cancer: meta-analysis of randomised controlled trials. Lancet Oncol. 2010;11(7):627-636.

14. Verma S, Strauss M. Angiotensin receptor blockers and myocardial infarction. BMJ. 2004;329(7477):1248-1249.

15. Sanoski CA. Aliskiren: an oral direct renin inhibitor for the treatment of hypertension. Pharmacotherapy. 2009;29(2):193-212.

16. White WB, Bresalier R, Kaplan AP, et al. Safety and tolerability of the direct renin inhibitor aliskiren: a pooled analysis of clinical experience in more than 12,000 patients with hypertension. J Clin Hypertens (Greenwich). 2010;12(10):765-775.

17. Bezencon O, Bur D, Weller T, et al. Design and preparation of potent, nonpeptidic, bioavailable renin inhibitors. J Med Chem. 2009; 52(12):3689-3702.

18. Tice CM, Xu Z, Yuan J, et al. Design and optimization of renin inhibitors: Orally bioavailable alkyl amines. Bioorg Med Chem Lett. 2009; 19(13):3541-3545.

19. Fyhrquist F, Saijonmaa O. Renin-angiotensin system revisited. J Intern Med. 2008;264(3):224-236.

20. Siragy HM. Comparing angiotensin II receptor blockers on benefits beyond blood pressure. Adv Ther. 2010;27(5):257-284.

21. Zheng Z, Shi H, Jia J, Li D, Lin S. A systematic review and metaanalysis of aliskiren and angiotension receptor blockers in the management of essential hypertension. J Renin Angiotensin Aldosterone Syst. 2010 Nov 8. [Epub ahead of print].

22. Parving HH, Persson F, Lewis JB, Lewis EJ, Hollenberg NK. Aliskiren combined with losartan in type 2 diabetes and nephropathy. $N$ Engl $J$ Med. 2008;358(23):2433-2446. 
23. McMurray JJ, Pitt B, Latini R, et al. Effects of the oral direct renin inhibitor aliskiren in patients with symptomatic heart failure. Circ Heart Fail. 2008;1:17-24.

24. Solomon SD, Appelbaum E, Manning WJ, et al. Effect of the direct renin inhibitor aliskiren, the angiotensin receptor blocker losartan, or both, on left ventricular mass in patients with hypertension and left ventricular hypertrophy. Circulation. 2009;119(4):530-537.

25. Solomon SD, Hee SS, Shah A, et al. Effect of the direct renin inhibitor aliskiren on left ventricular remodelling following myocardial infarction with systolic dysfunction. Eur Heart J. 2011. [Epub ahead of print].

26. Mazzolai L, Burnier M. Comparative safety and tolerability of angiotensin II receptor antagonists. Drug Saf. 1999;21(1):23-33.

27. Cozaar $^{\mathbb{R}}$ (losartan potassium tablets) [prescribing information]. 2006. Merck and Co., Inc, Whitehouse Station, NJ.

28. Diovan ${ }^{\circledR}$ (valsartan) Tablets [prescribing information]. 2008. Novartis Pharmaceuticals Corporation, East Hanover, NJ.

29. Julius S, Kjeldsen SE, Weber M, et al. Outcomes in hypertensive patients at high cardiovascular risk treated with regimens based on valsartan or amlodipine: the VALUE randomised trial. Lancet. 2004; 363(9426):2022-2031.

30. McMurray J. Angiotensin receptor blockers and myocardial infarction: analysis of evidence is incomplete and inaccurate. BMJ. 2005; 330(7502):1269.

31. Opie LH. Angiotensin receptor blockers and myocardial infarction: direct comparative studies are needed. BMJ. 2005;330(7502):1270-1271.

32. Lewis EJ. Angiotensin receptor blockers and myocardial infarction: results reflect different cardiovascular states in patients with types 1 and 2 diabetes. BMJ. 2005;330(7502):1269-1270.

33. Tsuyuki RT, McDonald MA. Angiotensin receptor blockers do not increase risk of myocardial infarction. Circulation. 2006;114(8): $855-860$.

34. Yousef ZR, Leyva F, Gibbs C. Angiotensin receptor blockers and myocardial infarction: cautions voiced are biologically credible. $B M J$. 2005;330(7502):1270-1271.

35. Verdecchia P, Angeli F, Gattobigio R, Reboldi GP. Do angiotensin II receptor blockers increase the risk of myocardial infarction? Eur Heart J. 2005;26(22):2381-2386.

36. McDonald MA, Simpson SH, Ezekowitz JA, Gyenes G, Tsuyuki RT. Angiotensin receptor blockers and risk of myocardial infarction: systematic review. BMJ. 2005;331(7521):873.

37. Volpe M, Mancia G, Trimarco B. Angiotensin II receptor blockers and myocardial infarction: deeds and misdeeds. J Hypertens. 2005;23(12): 2113-2118.

38. Cheung BM, Cheung GT, Lauder IJ, Lau CP, Kumana CR. Meta-analysis of large outcome trials of angiotensin receptor blockers in hypertension. J Hum Hypertens. 2006;20(1):37-43.

39. Messerli FH, Bangalore S, Ruschitzka F. Angiotensin receptor blockers: baseline therapy in hypertension? Eur Heart J. 2009;30(20): 2427-2430.

40. Walker E, Hernandez AV, Kattan MW. Meta-analysis: Its strengths and limitations. Cleve Clin J Med. 2008;75(6):431-439.

41. Suzuki H, Kanno Y. Effects of candesartan on cardiovascular outcomes in Japanese hypertensive patients. Hypertens Res. 2005;28(4): 307-314.

42. Yusuf S, Teo KK, Pogue J, et al. Telmisartan, ramipril, or both in patients at high risk for vascular events. $N$ Engl J Med. 2008;358(15): $1547-1559$

43. Yusuf S, Teo K, Anderson C, et al. Effects of the angiotensin-receptor blocker telmisartan on cardiovascular events in high-risk patients intolerant to angiotensin-converting enzyme inhibitors: a randomised controlled trial. Lancet. 2008;372(9644):1174-1183.

44. McMurray JJ, Holman RR, Haffner SM, et al. Effect of valsartan on the incidence of diabetes and cardiovascular events. N Engl J Med. 2010; 362(16):1477-1490.

45. Sawada T, Yamada H, Dahlöf B, Matsubara H. Effects of valsartan on morbidity and mortality in uncontrolled hypertensive patients with high cardiovascular risks: KYOTO HEART Study. Eur Heart J. 2009; 30(20):2461-2469.
46. Mochizuki S, Dahlof B, Shimizu M, et al. Valsartan in a Japanese population with hypertension and other cardiovascular disease (Jikei Heart Study): a randomised, open-label, blinded endpoint morbiditymortality study. Lancet. 2007;369(9571):1431-1439.

47. Massie BM, Carson PE, McMurray JJ, et al. Irbesartan in patients with heart failure and preserved ejection fraction. N Engl J Med. 2008; 359(23):2456-2467.

48. Yusuf S, Diener HC, Sacco RL, et al. Telmisartan to prevent recurrent stroke and cardiovascular events. $N$ Engl J Med. 2008;359(12): $1225-1237$.

49. Cohn JN, Tognoni G. A randomized trial of the angiotensin-receptor blocker valsartan in chronic heart failure. N Engl J Med. 2001;345(23): $1667-1675$.

50. Schrader J, Luders S, Kulschewski A, et al. Morbidity and Mortality After Stroke, Eprosartan Compared with Nitrendipine for Secondary Prevention: principal results of a prospective randomized controlled study (MOSES). Stroke. 2005;36(6):1218-1226.

51. Goldstein MR, Mascitelli L, Pezzetta F. Angiotensin-receptor blockade, cancer, and concerns. Lancet Oncol. 2010;11(9):817-818.

52. Kanehira T, Tani T, Takagi T, Nakano Y, Howard EF, Tamura M. Angiotensin II type 2 receptor gene deficiency attenuates susceptibility to tobacco-specific nitrosamine-induced lung tumorigenesis: involvement of transforming growth factor-b-dependent cell growth attenuation. Cancer Res. 2005;65(17):7660-7665.

53. Clere N, Corre I, Faure S, et al. Deficiency or blockade of angiotensin II type 2 receptor delays tumorigenesis by inhibiting malignant cell proliferation and angiogenesis. Int J Cancer. 2010;127(10): 2279-2291.

54. Meredith PA, McInnes GT. Angiotensin-receptor blockade, cancer, and concerns. Lancet Oncol. 2010;11(9):819.

55. Lithell H, Hansson L, Skoog I, et al. The Study on Cognition and Prognosis in the Elderly (SCOPE): principal results of a randomized double-blind intervention trial. J Hypertens. 2003;21(5): 875-886.

56. Bangalore S, Kumar S, Kjeldsen SE, et al. Antihypertensive drugs and risk of cancer: network meta-analyses and trial sequential analyses of 324,168 participants from randomised trials. Lancet Oncol. 2011; 12(1):65-82.

57. The ARB Trialists Collaboration. Effects of telmisartan, irbesartan, valsartan, candesartan, and losartan on cancers in 15 trials enrolling 138769 individuals. J Hypertens. 2011;29(4):623-635.

58. Huang CC, Chan WL, Chen YC, et al. Angiotensin II receptor blockers and risk of cancer in patients with systemic hypertension. Am J Cardiol. 2011;107(7):1028-1033.

59. FDA Drug Safety Communication. Ongoing safety review of the angiotensin receptor blockers and cancer. 2010. Available at: http:// www.fda.gov/Drugs/DrugSafety/PostmarketDrugSafetyInformationforPatientsandProviders/ucm218845.htm. Accessed March 2011.

60. Tekturna ${ }^{\circledR}$ (aliskiren) Tablets, Oral [prescribing information]. 2010. Novartis Pharmaceuticals Corporation, East Hanover, NJ.

61. Atacand $\mathrm{d}^{\circledR}$ (candesartan cilexetil) Tablets [prescribing information]. 2009. AstraZeneca LP, Wilmington, DE.

62. Avapro ${ }^{\circledR}$ (irbesartan) Tablets [prescribing information]. 2007. Bristol Myers Squibb Sanofi-Synthelabo Partnership, New York, NY.

63. Micardis $^{\circledR}$ (telmisartan) Tablets [prescribing information]. 2009. Boehringer Ingelheim Pharmaceuticals, Inc., Ridgefield, CT.

64. Teveten ${ }^{\circledR}$ (eprosartan mesylate) Tablets [prescribing information]. 2007. Abbott Laboratories, North Chicago, IL.

65. Benicar ${ }^{\circledR}$ (olmesartan medoxomil) Tablets [prescribing information]. 2009. Daiichi Sankyo, Inc., Parsippany, NJ.

66. Solomon SD, Wang D, Finn P, et al. Effect of candesartan on causespecific mortality in heart failure patients: the Candesartan in Heart failure Assessment of Reduction in Mortality and morbidity (CHARM) program. Circulation. 2004;110(15):2180-2183.

67. Pfeffer MA, Swedberg K, Granger CB, et al. Effects of candesartan on mortality and morbidity in patients with chronic heart failure: the CHARM-Overall programme. Lancet. 2003;362(9386):759-766. 
68. McMurray JJ, Ostergren J, Swedberg K, et al. Effects of candesartan in patients with chronic heart failure and reduced left-ventricular systolic function taking angiotensin-converting-enzyme inhibitors: the CHARM-Added trial. Lancet. 2003;362(9386):767-771.

69. Granger CB, McMurray JJ, Yusuf S, et al. Effects of candesartan in patients with chronic heart failure and reduced left-ventricular systolic function intolerant to angiotensin-converting-enzyme inhibitors: the CHARM-Alternative trial. Lancet. 2003;362(9386):772-776.

70. Yusuf S, Pfeffer MA, Swedberg K, et al. Effects of candesartan in patients with chronic heart failure and preserved left-ventricular ejection fraction: the CHARM-Preserved Trial. Lancet. 2003;362(9386):777-781.

71. Pfeffer MA, McMurray JJ, Velazquez EJ, et al. Valsartan, captopril, or both in myocardial infarction complicated by heart failure, left ventricular dysfunction, or both. N Engl J Med. 2003;349(20) 1893-1906.

72. McMurray J, Solomon S, Pieper K, et al. The effect of valsartan, captopril, or both on atherosclerotic events after acute myocardial infarction: an analysis of the Valsartan in Acute Myocardial Infarction Trial (VALIANT). J Am Coll Cardiol. 2006;47(4):726-733.
73. Dahlöf B, Devereux RB, Kjeldsen SE, et al. Cardiovascular morbidity and mortality in the Losartan Intervention For Endpoint reduction in hypertension study (LIFE): a randomised trial against atenolol. Lancet. 2002;359(9311):995-1003.

74. Dickstein K, Kjekshus J. Effects of losartan and captopril on mortality and morbidity in high-risk patients after acute myocardial infarction: the OPTIMAAL randomised trial. Optimal Trial in Myocardial Infarction with Angiotensin II Antagonist Losartan. Lancet. 2002; 360(9335):752-760.

75. Berl T, Hunsicker LG, Lewis JB, et al. Cardiovascular outcomes in the Irbesartan Diabetic Nephropathy Trial of patients with type 2 diabetes and overt nephropathy. Ann Intern Med. 2003;138(7):542-549.

76. Brenner BM, Cooper ME, de Zeeuw D, et al. Effects of losartan on renal and cardiovascular outcomes in patients with type 2 diabetes and nephropathy. N Engl J Med. 2001;345(12):861-869.

77. Pitt B, Poole-Wilson PA, Segal R, et al. Effect of losartan compared with captopril on mortality in patients with symptomatic heart failure: randomised trial--the Losartan Heart Failure Survival Study ELITE II. Lancet. 2000;355(9215):1582-1587.
Vascular Health and Risk Management

\section{Publish your work in this journal}

Vascular Health and Risk Management is an international, peerreviewed journal of therapeutics and risk management, focusing on concise rapid reporting of clinical studies on the processes involved in the maintenance of vascular health; the monitoring, prevention and treatment of vascular disease and its sequelae; and the involvement of

\section{Dovepress}

metabolic disorders, particularly diabetes. This journal is indexed on PubMed Central and MedLine. The manuscript management system is completely online and includes a very quick and fair peer-review system, which is all easy to use. Visit http://www.dovepress.com/ testimonials.php to read real quotes from published authors. 